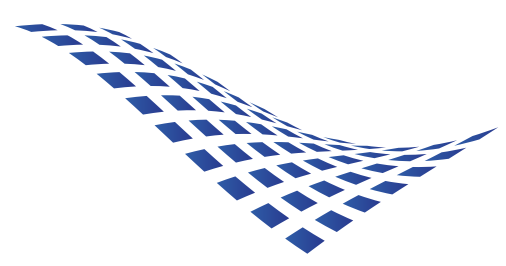

MOHAMMED VI

$P$ O L L Y T E C H

U $N|V E R S| T Y$ SCIENCES ECONOMIQUES

Do Remittances Mitigate COVID-19 Employment Shock on Food Insecurity? Evidence from Nigeria

CAHIER

DE RECHERCHE

21-07

Al-mouksit Akim

Firmin Ayivodji

Jeffrey Kouton 


\title{
Do Remittances Mitigate COVID-19 Employment Shock on Food Insecurity? Evidence from Nigeria
}

\author{
Al-mouksit Akim*, Firmin Ayivodji, and Jeffrey Kouton
}

April 22, 2021

\begin{abstract}
The objective of this paper is to assess the mitigating role of remittances during the adverse COVID-19 employment shock on Nigeria's food insecurity. Based on pre-COVID-19 and postCOVID-19 surveys, we use a difference-in-difference approach while controlling for the time and household fixed effects. Results indicate that remittances are mitigating the negative consequences of COVID-19 employment shocks, especially in the short run. We find that $100 \%$ of the deterioration in food insecurity, owing to the shock, is offset by the remittances received. While the adverse effects of the shock persist over time, the mitigation effect of remittances appears to be effective only at the early stages of the pandemic, however. Furthermore, the mitigation effect of remittances seems heterogeneous regarding the origin of remittances, residence area, and poverty status. The mitigation effect of remittances is higher for remittances from abroad than for Domestic ones. We also find a higher mitigating effect of remittances in the rural area and for non-poor households. Finally, our results shed light on the capital channel as a crucial mechanism explaining the mitigation effect of remittances. Notably, findings suggest that formal financial inclusion, capital ownership like livestock or rental earnings, amplifies the attenuating effect of remittances.
\end{abstract}

JEL Classification: E21, E24, I12, O12, O55.

Keywords: COVID-19; Remittances; Shock; Food Insecurity; Africa.

\footnotetext{
*Akim: AIRESS, FGSES, Mohammed VI Polytechnic University (email: akim.almouksit@um6p.ma). Ayivodji: Université de Montréal (email: firmin.ayivodji@umontreal.ca). Kouton: Ecole Nationale Supérieure de Statistique et d'Economie Appliquée (email: jeffrey.kouton@ensea.edu.ci). We thank Juste Djabakou and the participants of UdeM-CIREQ PhD workshop series for their helpful comments. The opinions are those of the authors and do not represent the official position of their affiliated institutions.
} 


\section{Introduction}

The recent COVID-19 pandemic poses unprecedented challenges for governments around the world. The rapid spread of the virus and the subsequent death toll have led the policymakers to enact unprecedented strict movement restriction measures to slow down its transmission. Although these measures are intended to prevent the loss of human life, their economic cost is worth questioning. The COVID-19 outbreak is affecting economic activity and, consequently the household economics through two main channels representing supply and demand adverse shocks. The first channel is health (hereafter, the "health channel"), as workers getting sick results in lower productivity. At the same time, consumers may react to the outbreak by significantly reducing their demand for goods/services requiring interpersonal contact $^{1}$ (Wren-Lewis, 2020). The second channel is the government's movement restriction measures, especially the lockdown (hereafter, the "lockdown channel") to contain the pandemic. These measures are causing sizeable economic disruptions simultaneously. Businesses across most industries have been constricted because of stay-at-home orders and other movement restrictions measures. For instance, most countries have closed their borders, and entire industries (restaurants, stores, etc.) have been shut-down for a certain length of time.

The immediate consequences of such major disruptions have been a significant drop in income and high unemployment, or job losses, which have affected the household welfare. It has been reported that in 2020, the COVID-19 shock could translate into a decrease of $2.1 \%$ of economic activity in the Africa region alone (Arezki Rabah and Koffi, 2021). This represents the continent's first recession in half a century and could push about 39 million people into extreme poverty ${ }^{2}$ in 2021 (Arezki Rabah and Koffi, 2021). The pandemic may also dramatically worsen food insecurity in this region (Pereira and Oliveira, 2020). In parallel to prediction-based studies, the rapidly growing literature on real-time household surveys supports these forecasts. Using online survey data, Kansiime et al. (2020) find that, during the pandemic, the proportion of food insecure respondents has increased by $38 \%$ and $44 \%$ in Kenya and Uganda,respectively, compared with the period before the pandemic. However, the approach and the data used in their study may be questioned for several reasons. First, their data may suffer from a lack of representativeness. Second, their approach, based on a before-after period comparison of food insecurity, may be biased. For instance, their approach does not control for biases in time-trend-related factors such as seasonality of harvest or planting period. Despite these limitations, the findings provide suggestive evidence of the tension caused by the COVID-19 shock and are supported by other studies investigating the Nigeria setting. Based on a high-frequency household survey, Amare et al. (2020) accounts for some of the limitations in Kansiime et al. (2020)'s study. They use a difference-in-difference (DiD) methodology to assess the impact of the COVID-19 shock on food insecurity. Using a similar approach, Adjognon, Bloem, and Sanoh (2020)'s results confirm the adverse effect of COVID-19 on household food insecurity in Mali, particularly in urban areas. Amare et al. (2020) find similar results in Nigeria settings and provide evidence of two potential channels affecting household economics: labor market participation and

\footnotetext{
${ }^{1}$ restaurants, travel, haircuts, etc.

${ }^{2}$ In terms of proportion, extreme poverty could increase by $2.9 \%$ points in 2021 .
} 
food prices.

In Sub-Saharan Africa, several factors may be exacerbating the COVID-19 shock on food insecurity. Households from this region are particularly exposed to adverse shocks, where nearly $81 \%$ of the population is not covered by social protection compared with $38 \%$ in Latin America and the Caribbean, and 40\% in South Asia in 2016 . Balde, Boly, and Avenyo (2020) find that the COVID19 impact is higher among informal workers. These workers are more likely to experience job loss and hardship in trying to meet their basic needs. The lack of access to social protection is even more concerning, given the imperfections in markets and credit constraints. Financial inclusion in Sub-Saharan Africa region is the lowest in the world (Demirgüç-Kunt, 2014). Evidence indicates that households with no access to social protection or financial services, such as poor households and informal workers, are likely to experience considerably greated food insecurity (Amare et al., 2020; Balde, Boly, and Avenyo, 2020).

Against a backdrop of market failures and weak social protection, households' alternatives to mitigating COVID-19 adverse shocks are limited. Households tend to rely on private insurance for risk-sharing based on informal mechanisms, including remittances from migrants or relatives living within the same country or abroad. Evidence from the insurance-related migration literature suggests that remittances can function as an insurance mechanism to smooth household consumption. Based on a panel dataset of developing countries, Combes and Ebeke (2011); Mondal and Khanam (2018); Beaton, Cevik, and Yousefi (2018) find that remittances significantly decrease consumption volatility, highlighting hence their smoothing-consumption role. From a micro perspective, using a household survey, Amuedo-Dorantes and Pozo (2011)' find similar results, indicating a decrease in income volatility in the Mexican setting. Meanwhile, Yang and Choi (2007) find that remittances increase in response to a rainfall shock, partially offsetting the resulting decline in income in the Philippines. Instead of aggregate shocks, such as rainfall shocks, Beuermann, Ruprah, and Sierra (2016); Akim (2018) investigate the remittance insurance function against idiosyncratic shocks such as health or death shocks, in Jamaica and Mali, respectively. Their results indicate that remittances can help households to smooth their consumption when facing idiosyncratic shocks.

Although the insurance-related migration literature provides evidence of the insurance function of remittances, the findings are not necessarily generalizable to the context of COVID-19 shock and the disruptions related to government measures. The COVID-19 shock is of a different nature in many aspects, including its magnitude and mechanisms. The mitigating role of remittances on adverse COVID-19 shock has not been explored insufficiently in the rapidly growing COVID19-related literature. Balde, Boly, and Avenyo (2020) analyze how remittances can cushion the adverse effects of COVID-19 on the ability of informal worker in meeting basic needs. They find that informal workers in Senegal who receive remittances face fewer challenges in meeting their basic needs in Senegal, whereas this is not the case in Mali or Burkina Faso. Nonetheless, they use an online survey that is subject to a serious bias as it lacks representativeness, similar to that used by Kansiime et al. (2020). Besides the representativeness bias, their estimates may suffer from

\footnotetext{
${ }^{3}$ World Bank, ASPIRE: THE ATLAS OF SOCIAL PROTECTION - INDICATORS OF RESILIENCE AND EQUITY.
} 
endogeneity bias as cross-sectional probit regressions are used without controlling for selection bias related to unobservables.

This paper aims to assess the mitigating role of remittances during the adverse COVID-19 employment shock on Nigeria's food insecurity. Using pre-COVID-19 face-to-face surveys and postCOVID-19 phone surveys, we exploit temporal changes in food insecurity and COVID-19 employment shocks measured at the household level, to design a difference-in-difference (DiD) strategy. Our findings contribute to expanding the rapidly growing COVID-19 literature. Given the data at hand and the methodology, our paper expands on the works of Amare et al. (2020) and Balde, Boly, and Avenyo (2020). However, we distinguish from these paper in following respects. The primary focus of our paper is on the role of remittances in mitigating the COVID-19 adverse shocks, while that of Amare et al. (2020)'s is on an assessment of the actual magnitude of the shock and its potential impact pathways. In contrast to Balde, Boly, and Avenyo (2020), we use a more robust approach that addresses the potential endogeneity arising from selection bias. Furthermore, we add to the literature by exploiting our panel data's length to investigate the persistence of the shock over time and the lasting effect of the remittances' mitigating effect.

Our paper likewise contributes to the nascent insurance migration literature. Although the role of remittances in smoothing consumption has been highlighted in the literature, insufficient attention has been given to the underlying mechanisms. We expand the scope of shocks considered thus far in the insurance-migration literature and shed light on one of the two potential mechanisms through which remittances may protect households against adverse shocks. First, remittances can function as an ex-post mitigating shock mechanism. Households may receive remittances immediately following the shock, subsequently increasing their income. There is evidence of an increase in remittances following shocks such as natural disasters or weather shocks (Gubert, 2002; Yang and Choi, 2007; David, 2011; Lara, 2016). However, this ex-post mechanism is unlikely to operate in the case of shocks from a global pandemic such as COVID-19, as remittances are expected to decrease sharply (Ratha et al., 2020). Second, remittances can function as an ex-ante mitigating shock mechanism. By releasing budgetary constraints, remittances may allow the households to increase savings and subsequently cope with the shock. There is evidence of remittances stimulating financial services, such as savings and credit, (Anzoategui, Demirgüç-Kunt, and Pería, 2014; Ambrosius and Cuecuecha, 2016) and even substituting for credits in the case of a health shock (Ambrosius and Cuecuecha, 2013).

We focus on the ex-ante mechanism by testing whether household capital ownership amplifies the mitigating effect of remittances. Specifically, we test whether the remittances' attenuating effect is higher for households with capital. We adopt a broad definition of capital that includes savings/credit, livestock, and rental earnings to account for Sub-Saharan setting. In that perspective, households capital ownership refers to two situations in our paper. The first is households that have an account in a financial institutions. We reasonably assume that these households are likely to have access to savings or credit, consistent with the evidence that remittances stimulate financial services that help households cope with the shock. The second situation is households that own livestock or receive rental earnings. Evidence that poor and rural households rely more on such 
assets as a coping mechanism instead of savings (Nikoloski, Christiaensen, and Hill, 2018), motivates our decision to include livestock and rental earnings in the capital mechanism test. Livestock can attenuate deterioration in household food security through their sale (Fafchamps, Udry, and Czukas, 1998). Some types of livestock can also provide food for households, especially during hard times. For instance, poultry and cattle can provide meat, milk, and eggs. As remittances ease budgetary constraints, some households might, theoretically, acquire more goods, including livestock. We believe assets such as livestock, or those generating rental earnings, are worth considering as a potential consumption smoothing mechanisms.

Nigeria arguably offers an appealing context to investigate the remittances-mitigating role of COVID-19 shock. On the one hand, the Nigerian economy is expected to be hardly affected due to economic vulnerabilities that was prevailing even before the shock. In 2018, the country included the largest share of the extreme poor population in the Sub-Saharan Africa region, with $20 \%$ of this population living in Nigeria ${ }^{4}$. The country also faces critical challenges in terms of food security, as illustrated by its low food consumption score and high-calorie deficiency ${ }^{5}$. At the same time, COVID-19 has had a huge impact on Nigeria, with 161,737 confirmed $\operatorname{cases}^{6}$ (38\% of the total cases in West Africa) as of March 21, 2021. Forecasts suggest that the COVID-19 pandemic and the related disruptions may result in 5 million additional poor people ${ }^{7}$ and also put more tension on food systems that are already vulnerable. On the other hand, Nigeria ranks among the top 10 remittance-recipient countries in Sub-Saharan Africa ${ }^{8}$. Remittances represent considerable financial flow to beneficiary households, which may reduce poverty and inequality (Odozi, Awoyemi, and Omonona, 2010). Notably, they may also stimulate financial inclusion, which constitutes a potential mechanism of consumption smoothing. There is evidence that remittances increase the likelihood of using formal financial services, such as deposit accounts and Internet/mobile banking (Ajefu and Ogebe, 2019).

We find that remittances can mitigate the negative consequences of COVID-19 employment shock on Nigeria's food insecurity. Households receiving remittances seem to experience a lower deterioration of their food security compared with non-beneficiary households in the short run. The dramatic rise in food insecurity associated with the shock appears to be $100 \%$ offset by the remittances received. The mitigating effect of remittances decline over time, while the adverse impact of the shock persists, however. Interestingly, our results indicate that this mitigating effect may operate through the capital mechanism, notably financial inclusion, rental earnings, or livestock ownership. We find that the mitigating effect of remittances is significantly amplified when households have access or hold to capital. The heterogeneity of the remittance mitigating effect on remittance origin, residence area, and household poverty status is worth highlighting as well. The remittance cushion effect appears to have a greater impact for remittances from abroad than for Domestic ones,

\footnotetext{
${ }^{4}$ https : //openknowledge.worldbank.org/bitstream/handle/10986/34496/9781464816024Ch1.pdf

${ }^{5}$ https://ebrary.ifpri.org/digital/collection/p15738coll16/id/1248

${ }^{6}$ African Development Bank (March 2021), Weekly Data flach on COVID-19 in Africa: the situation as of Sunday, March 21, 2021.

${ }^{7}$ https://blogs.worldbank.org/opendata/impact-covid-19-coronavirus-global-poverty-why-sub-saharan-africamight-be-region-hardest

${ }^{8}$ https://www.knomad.org/sites/default/files/2019-04/Migrationanddevelopmentbrief31.pdf
} 
as those from abroad are considerably larger. Our results also suggest that remittances mitigate adverse shocks, mainly in rural areas and for non-poor households. Concerning poor households, there is evidence of a mitigating effect of remittances for those receiving International remittances. In the urban areas, our findings also indicate remittance mitigation effects only for households in capital cities (Lagos/Abuja) receiving International remittances.

The remainder of this paper is organized into four sections. Section 2 presents our data sources and variables. Section 3 describes our methodology, and Section 4 discusses our results and robustness tests. Section 5 provides conclusions arising from our findings.

\section{Data sources and variables}

\subsection{Data and representativeness}

This paper combines data from a pre-COVID-19 face-to-face survey and a post-COVID-19 phone survey to assess the mitigating role of remittances during adverse COVID-19 employment shock on Nigeria's food insecurity. The surveys are part of the World Bank's Living Standards Measurement Study - Integrated Surveys on Agriculture (LSMS-ISA). The LSMS-ISA data for Nigeria include the General Household Survey (GHS) conducted 2018-19. The GHS panel sample used in our study includes 4,976 households interviewed in two waves: during the post-planting period from July to September 2018 and during the post-harvest period in January/February 2019. This sample of households is nationally representative and spans the six geopolitical zones that divide up the country.

Additionally, to track the impact of the pandemic, the National Bureau of Statistics implemented the Nigeria COVID-19 National Longitudinal Phone Survey (COVID-19 NLPS-2020) on a nationally representative sample of households drawn from those interviewed in the 2018/2019 GHS wave 4 . The extensive information collected in the GHS panel just over a year prior to the pandemic provides abundant background information on COVID-19 NLPS households, which can be leveraged to assess the differential impacts of the pandemic in the country.

Among the 4,976 households interviewed in the 2018 post-harvest timeframe, 4,934 (99.2\%) provided at least one telephone number. Out of the full sample of households with phone numbers, 3,000 households were randomly selected for the NLPS. Of those contacted, 94\% $(1,950)$ completed phone interviews. These 1,950 households constitute the final successful sample and will be contacted in subsequent rounds of the survey. To create a balanced panel across rounds, we merged these households with the GHS panel 2019 data and retained those households with complete information in both rounds $(\mathrm{N}=1,950)$.

To manage selection bias associated with nonresponse and potential attrition in a phone survey and to construct nationally representative statistics, appropriate sampling weights must be built and applied. The LSMS-ISA team constructed the sampling weights using the weights for the GHS panel as the basis, with further adjustment for the attrition issue in the phone survey. The weights 
for the final sample of households from the phone survey were calculated in several stages (see NBS and WB (2020) for details). These weights are shown to ensure the comparable distribution of observable characteristics (state, urban/rural, household size, sex of the household head, age, asset ownership, education, etc.) from the GHS panel and the COVID-19 phone survey.

Table 1 presents the weighted and unweighted summary statistics of selected variables and observable household characteristics in both rounds (pre-COVID and post-COVID). Analysis of the unweighted GHS Panel and NLPS-2020 columns shows how attrition or nonresponse can affect the statistics of household characteristics. The unweighed column of NLPS-2020 suggests that more households with a higher standard of living responded to the phone survey. These households are more likely to own certain goods such as regular mobile phones, smartphones, televisions, cars, and generators. Following the weighting adjustments and calibration, the weighted estimates obtained from the GHS panel and NLPS samples match very closely across all dimensions. The use of these weights reduces the unweighted differences markedly in the observable characteristics of the GHS panel sample and phone survey samples. This is encouraging, as most of these household characteristics are not expected to change significantly in such a short period. Consistent with Wooldridge (2007) and Korinek, Mistiaen, and Ravallion (2007), using these corrected sampling weights reduces attrition bias and provides appropriate and representative statistics.

Table 1: Sample composition : Pre-COVID-19 vs Post-COVID-19

\begin{tabular}{lcccc}
\hline \multirow{2}{*}{ Characteristic } & Pre-COVID-19 & (GHS-2019) & \multicolumn{2}{c}{ Post-COVID-19 (NLPS 2020) } \\
\cline { 2 - 5 } & Unweighted & Weighted & Unweighted & Weighted \\
\hline Sample size (successful interviews) & 4976.0 & - & 1950.0 & - \\
Average household size (family size) & 5.3 & 5.5 & 5.5 & 5.5 \\
Household head characteristics & & & & 18.6 \\
\hline Female head (\%) & 20.1 & 18.6 & 19.1 & 49.2 \\
Age of head (years) & 49.8 & 48.8 & 49.4 & 74.4 \\
Literate (\%) & 72.8 & 74.4 & 79.4 & 20.6 \\
Education level of head & & & & 24.1 \\
None (on no school) & 22.2 & 20.5 & 15.8 & 4.0 \\
Primary & 24.6 & 24.1 & 24.6 & 23.9 \\
Junior secondary & 4.3 & 4.0 & 4.4 & 16.0 \\
Senior secondary & 23.3 & 23.9 & 26.7 & 11.4 \\
Tertiary & 16.7 & 16.0 & 21.7 & 66.0 \\
Religious/other & 8.9 & 11.5 & 6.8 & 26.8 \\
Asset ownership & & & & 48.1 \\
\hline Regular mobile phone & 66.1 & 65.4 & 71.1 & 18.7 \\
Smart phone & 26.5 & 26.7 & 32.9 & 9.4 \\
Television & 45.5 & 45.1 & 55.3 & 24.4 \\
Refrigerator & 18.0 & 17.3 & 23.4 & 12.5 \\
Car & 9.8 & 9.6 & 32.4 & \\
Generator & 26.3 & 24.6 & & \\
\hline \hline
\end{tabular}

Source : GHS-Panel wave 4 (2018/2019), COVID-19 NLPS 2020, Authors' calculations.

\subsection{Variable definition and descriptive statistics}

\section{COVID-19 employment shock}

The variable used to measure COVID-19 employment shock is extracted from the section on employment in the COVID-19 NLPS 2020 baseline household questionnaire. In particular, we are focused 
on: (1) if the respondent has been working before mid-March and, if not, (2) the main reason why the respondent stopped working. For all individuals responding "yes" to the first question, that is, they had been working before mid-March, we consider the following two reasons as representing employment shock: (1) Business/office closed due to coronavirus legal restrictions; and (2) not able to go to farm due to movement restrictions. This approach allows us to account for differences in the way households are affected by employment shocks due to COVID-19. Accordingly, our COVID-19 employment shock variable takes the value of 1 if any household member stopped working because his/her business/office was closed due to legal restrictions or he/she was unable go to the farm due to movement restrictions (Shocked household); it takes the value 0 in any other case (Not-shocked household).

Table 2 present the characteristics of the two group of households. Unsurprisingly, Shocked households are more likely to live in urban areas (Lagos/FCT or other urban) compared with Not-shocked households. This result is expected as the COVID-19 pandemic and the movement restrictions measures has started in urban areas. In line with the literature, we find that households engaged in non-farm family firms or wage work would experience more shocks than those working in agricultural activities. Moreover, results suggest that Shocked households are more endowed in terms of living standards and education than the Not-shockeded ones. The proportion of Shocked households in the top consumption quintile (23.8\%) is significantly higher than Not-shockeded households households (18.4\%). Shocked households own on average more assets, particularly refrigerators and cars. Regarding education level, literacy rate and household heads with secondary and tertiary education are proportionally higher within Shocked households than Not-shockeded households. These findings are in overall consistent with the new profile of the poor population induced by COVID-19 (Freije-Rodriguez and Woolcock, 2020).

\section{Remittances}

To create the remittance measurement variable, we use the GHS panel wave four and consider the post-harvest data from January and February 2019. The survey section on remittances is intended to capture remittances to household members aged ten years and older. We focus on the questions asking whether the individual received the following types of assistance from a non-household member in the past 12 months: monetary assistance and/or in-kind assistance. It should be noted that these two types of assistance are further grouped based on their origin in the questionnaire: "from abroad" and "from within Nigeria." Therefore, the remittance variable takes the value 1 if the individual received any assistance in the past 12 months, from abroad (International remittances) or from within Nigeria (Domestic remittances), and 0 otherwise. Based on this individual-level information, we aggregate at the household level and define three groups. First, the "non-beneficiary remittance " group includes households with any remittance recipient member. Second, the "International remittance" group includes households with at least one International remittance beneficiary. Third, the "Domestic remittance" group includes members receiving remittances originating solely within the country. Households with members receiving remittances from abroad and Domestically are included in the "International remittances" group. 
Table 2: Households characteristics at baseline (Post-harvest wave - 2018/2019)

\begin{tabular}{|c|c|c|c|c|}
\hline & $\begin{array}{c}\text { Shocked } \\
(1)\end{array}$ & $\begin{array}{c}\text { Not-shocked } \\
(2)\end{array}$ & $\begin{array}{l}\text { Difference } \\
(1)-(2)\end{array}$ & T-test \\
\hline \multicolumn{5}{|l|}{ Residence area } \\
\hline Lagos/FCT & 3.9 & 2.4 & 1.5 & $2.0^{* *}$ \\
\hline Other urban & 35.7 & 24.4 & 11.3 & $5.4^{* * *}$ \\
\hline Rural & 60.4 & 73.4 & -13.0 & $-6.1^{* * *}$ \\
\hline \multicolumn{5}{|c|}{ Socio-demographic characteristics } \\
\hline Average household size & 5.6 & 5.5 & 0.1 & 1.2 \\
\hline Female head $(\%)$ & 14.8 & 20.9 & -6.1 & $-3.3^{* * *}$ \\
\hline Age of head (years) & 46.5 & 50.7 & -4.2 & $-6.1^{* * *}$ \\
\hline Literate $(\%)$ & 80.5 & 77.3 & 3.2 & $4.8^{* * *}$ \\
\hline \multicolumn{5}{|c|}{ Education level of head (\%) } \\
\hline None (on no school) & 31.2 & 40.3 & -9.1 & $-4.0^{* * *}$ \\
\hline Primary & 20.2 & 26.3 & -6.1 & $-3.1^{* * *}$ \\
\hline Secondary & 29.8 & 19.1 & 10.7 & $5.5^{* * *}$ \\
\hline Tertiary & 18.7 & 14.3 & 4.4 & $2.6^{* * *}$ \\
\hline \multicolumn{5}{|l|}{ Asset ownership (\%) } \\
\hline Regular mobile phone & 77.1 & 75.3 & 1.8 & 0.9 \\
\hline Television & 48.6 & 47.8 & 0.8 & 0.4 \\
\hline Refrigerator & 23.3 & 16.1 & 7.2 & $4.0^{* * *}$ \\
\hline Car & 11.2 & 8.3 & 2.9 & $2.1^{* *}$ \\
\hline Generator & 23.9 & 24.6 & -0.7 & -0.3 \\
\hline \multicolumn{5}{|c|}{ Working status (\% Adults) } \\
\hline Agricultural activities & 20.5 & 32.5 & -12.0 & $-7.1^{* * *}$ \\
\hline Non-farm family enterprise & 36.2 & 31.1 & 5.1 & $3.0^{* * *}$ \\
\hline Wage work & 14.7 & 12.0 & 2.7 & $2.2^{* *}$ \\
\hline \multicolumn{5}{|l|}{ Consumption quintile (\%) } \\
\hline Q1 & 19.6 & 19.9 & -0.3 & -0.2 \\
\hline Q2 & 20.4 & 19.7 & 0.7 & 0.4 \\
\hline Q3 & 16.7 & 21.7 & -5.0 & $-2.7^{* * *}$ \\
\hline Q4 & 19.5 & 20.2 & -0.7 & -0.4 \\
\hline Q5 & 23.8 & 18.4 & 5.4 & $2.8^{* * *}$ \\
\hline Observations & 725 & 1225 & 1950 & \\
\hline
\end{tabular}

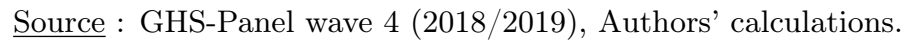

Note: Estimates are adjusted by the weights accounting for non-contact and non-response.

Figure 1 presents remittance distribution by sending origin consistent with other data sources and literature. This gives us confidence that our data are reliable, despite the attrition and nonresponse issues highlighted previously. Results indicate that most of the households do not receive any remittances $\left(68 \% \%^{9}\right)$. This percentage is similar to the proportion of households reporting never receiving remittances provided in the Afrobarometer survey ${ }^{10}$. Furthermore, our findings show that the household likelihood of households receiving Domestic remittances (27.9\%) is significantly higher than International remittances (4\%). However, average International remittances are overwhelmingly higher than Domestic ones. The average remittances from abroad are roughly 2.5 times those from within the country. The likelihood of International remittances is conditional based on International migration rates, which is relatively low $\left(0.6 \%\right.$ in $\left.2013^{11}\right)$. We find a similar propor-

\footnotetext{
${ }^{9}$ of the finale sample (1,950 households)

${ }^{10}$ Afrobarometer survey based on the online data analysis tool.

${ }^{11}$ World Bank (2016), Migration and Remittances Factbook 2016
} 
tion if we switch from household to individual scales when computing the likelihood of receiving remittances. The ratio between the number of International beneficiaries and the whole population, computed based on the data at hand, is estimated at $0.7 \%$.

Figure 1: Remittances distribution by sending origin (2018/2019)

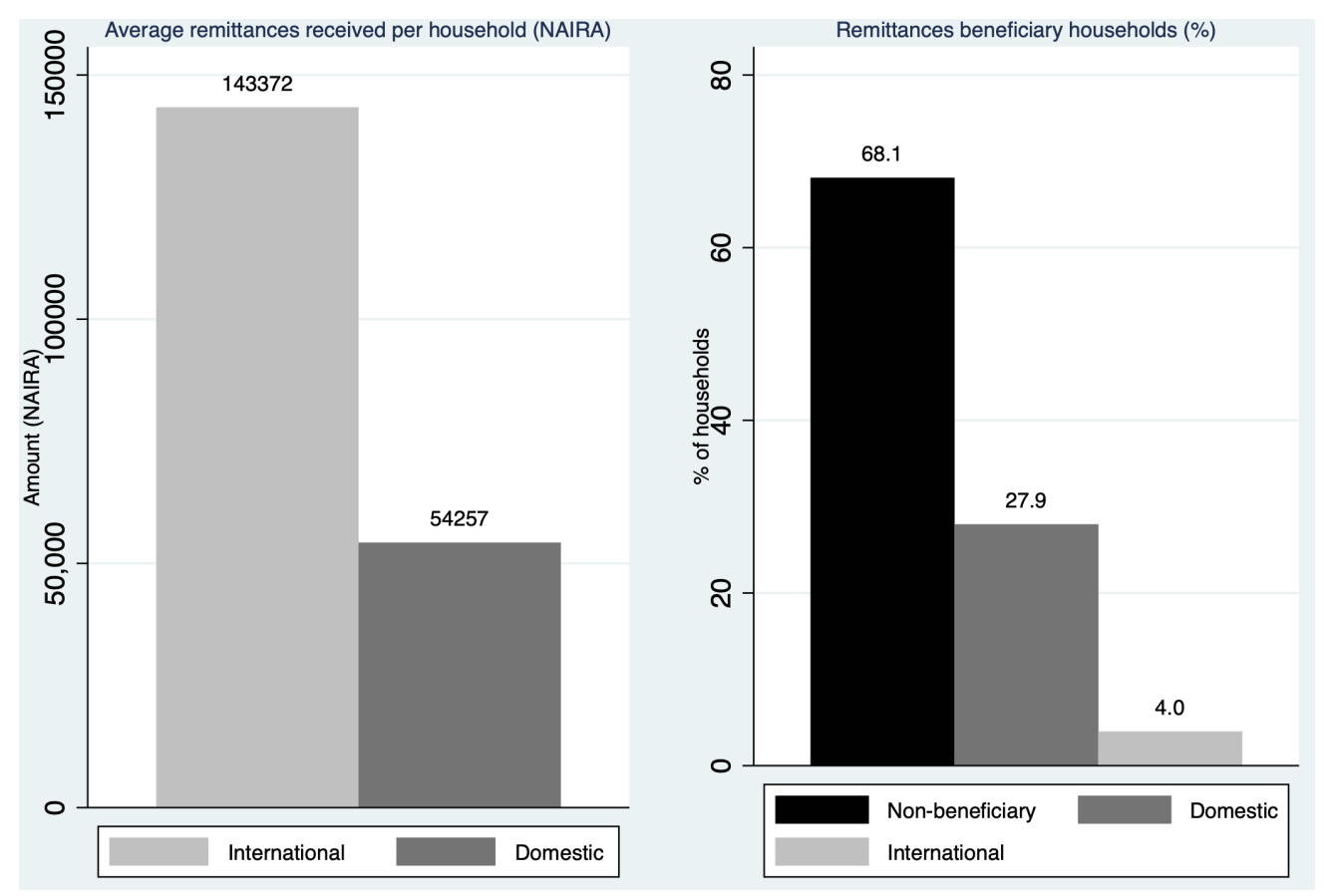

Source: GHS-Panel wave 4 (2018/2019), Authors' calculations.

Note: Estimates are adjusted by the weights accounting for non-contact and non-response.

\section{Food insecurity}

The food insecurity variable is constructed from data on food security captured consistently across rounds. This variable reflects household food shortage situations based on three yes/no questions related to the participants' last 30 days. These situations are: (1) skipping a meal because there was not enough money or other resources to get food; (2) ran out of food because of a lack of money or other resources; and (3) went without eating for a whole day because of a lack of money or other resources. To construct the variable, we took the following two steps. Step 1: transforming each of these situations into dummy variables; and Step 2: for each household, calculating the sum of the values of the three dummy variables constructed in Step 1. This procedure yields a food insecurity variable score that takes the following values: $0,1,2$, and 3 . In the case where the household replies no to all three situations, 0 is assigned. In the case where the household responds yes to only one of the situations, 1 is assigned; 2 is assigned if the households responds yes to two of the situations; and 3 is assigned if the household responds yes to all three situations. Consequently, the higher the score, the higher the food shortage that household faces.

Figure 2 presents the food insecurity score over the survey waves covering the period before the shock (2018 plantation and 2019 harvest) and after (May 2020). Overall, the food insecurity score increased sharply during COVID-19 for both household samples, those receiving remittances and 
those that did not. The increase is even higher for households not receiving remittances, especially those who are shocked. While the food insecurity score of non-beneficiary shocked households is lower than that of Not-shocked households in the period before the shock, the reverse is observed after the shock. If both groups experience a significant increase in food insecurity, food insecurity is even higher for the Shocked households than their Not-shocked counterparts. Nonetheless, the difference in food insecurity between Shocked and Not-shocked households seems lower within the recipient subgroup, suggesting that remittances may cushion the negative consequences of this subgroup's shock.

Figure 2: Average Food Insecurity Score over time

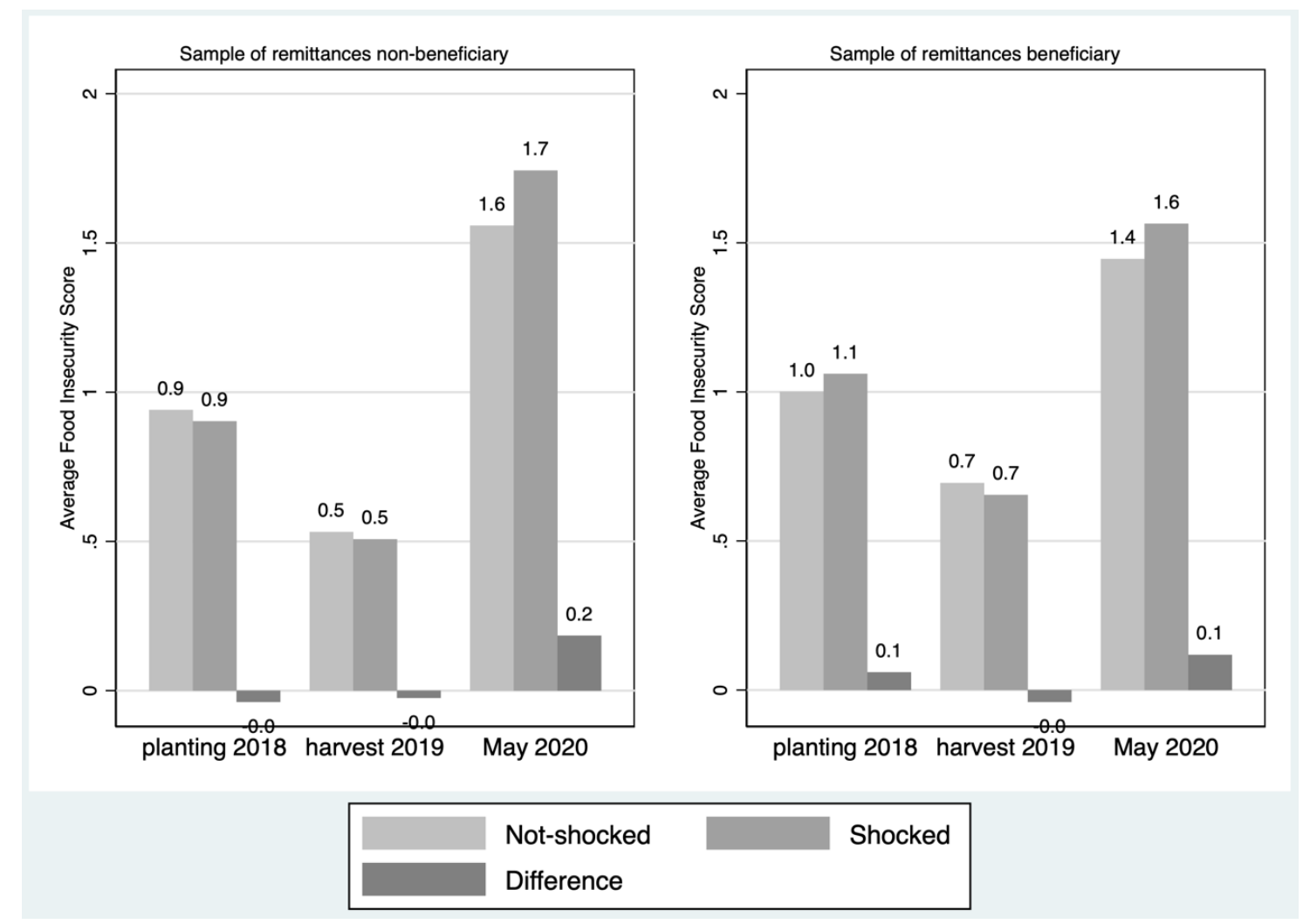

Source: GHS-Panel wave 4 (2018/2019), COVID-19 NLPS 2020, Authors' calculations.

Note: Estimates are adjusted by the weights accounting for non-contact and non-response.

\section{Methodology}

To examine the mitigating role of remittances during COVID-19 employment shock on food insecurity, we use a (DiD) model specified in equation (1). All estimates are adjusted by the weights accounting for noncontact and nonresponse. Consistent with Wooldridge (2007) and Korinek, Mistiaen, and Ravallion (2007), using this corrected sampling weight will allow limiting attrition bias based on the assumption that data are randomly missing conditional on the observables used to compute the weights:

$$
y_{h t}=\alpha+\beta_{0} \text { shock }_{h} \times \text { post }_{t}+\beta_{1} \text { shock }_{h} \times \text { post }_{t} \times \mathbb{1}_{\text {remittances }_{h}}+\delta_{h}+\mu_{t}+\epsilon_{h t}
$$


Where $y_{h t}$ represents the food insecurity outcome of the household $\mathrm{h}$ in period $\mathrm{t} . \alpha$ is the constant term. $\delta_{h}$ and $\mu_{t}$ are households and time-fixed effects to control for time-invariant and trendassociated omitted unobservable heterogeneity, respectively. Shock $k_{h}$ is a dummy variable indicating whether any member of the household stopped working due to coronavirus legal restrictions or was not able to farm due to movement restrictions. post $_{t}$ is a dummy variable taking the value 1 for the post-COVID-19 rounds and 0 for the pre-COVID-19 rounds. The coefficient $\boldsymbol{\beta}_{\mathbf{0}}$, associated with the shock variable, is expected to be positive $\left(\boldsymbol{\beta}_{\mathbf{0}}>\mathbf{0}\right)$, as it captures the adverse impact of the shock on food insecurity. The household-level defintion of the shock is more precise than the exposure to COVID-1912 or lockdown measured at the state level, as used by Amare et al. (2020). All households in a given area are not exposed to the COVID-19 shock in the same way, as they do not necessarily comply with lockdown measures. Compliance with lockdown measures depends on the poverty, trust in government, and economic/fiscal support measures (Bargain and Aminjonov, 2020a,b; Akim and Ayivodji, 2020).

$\mathbb{1}_{\text {remittances }_{h}}$ is a dummy indicating whether the household received remittances during the 12 last months. The coefficient $\boldsymbol{\beta}_{\mathbf{1}}$, associated with the interaction term, is our parameter of interest. This coefficient measures the mitigating effect of remittances on adverse shocks on food insecurity. Therefore, the hypothesis of the remittances' mitigating role is whether $\boldsymbol{\beta}_{\mathbf{1}}$ is negative, that is, $\left(\beta_{1}<0\right)$ :

$$
\beta_{1}=E\left[y_{h t} \mid \text { shock }_{h}=1, \text { post }_{t}=1, \mathbb{1}_{\text {remittances }_{h}}=1\right]-E\left[y_{h t} \mid \text { shock }_{h}=1, \text { post }_{t}=1, \mathbb{1}_{\text {remittances }_{h}}=0\right]
$$

We focus primarily on remittances before the COVID-19 shock occurs for identification issues purposes. The DiD method requires avoiding a variable affected by the shock among the explanatory ones. Current remittances are likely to be affected by the COVID-19 shock and subsequent government lockdown measures. Remittance inflows in Sub-Saharan Africa are projected to decline by $8.8 \%$ in comparison with 2019, mainly due to COVID-19 shocks (Ratha et al., 2020). As a consequence of the COVID-19 shock, migrants are likely to experience earning losses in the destination location, which may negatively affect their ability to send money back home. Government measures enacted in both destination and origin locations, such as the business shutdown ${ }^{13} /$ travel bans, are also likely to affect remittances. Evidence from High-Frequency Household surveys supports these forecasts. Of Nigerian households, $72 \%$ receiving remittances report experiencing a decrease in remittances in $2020^{14}$. Similarly, Ratha et al. (2020) find a decline in Nigerian remittance inflows by more than $45 \%$ in comparison with 2019.

The DID identification relies on the fundamental assumption of a parallel trend. In our case, this assumption means that food insecurity in a household shocked and not-shocked would have evolved in tandem in the absence of the shock. As this counterfactual situation is unobservable, we conduct a validity check that compares the food insecurity trend among both the shocked and

\footnotetext{
${ }^{12}$ Measured as the number of cases

${ }^{13}$ Including remittances service providers

${ }^{14}$ World Bank. "COVID-19 High-Frequency Monitoring Dashboard".The World Bank Group. Washington, DC.
} 
not-shocked groups prior to the shock. We reinforce the identification of the remittance-mitigating effect by conducting a placebo test. We run a placebo regression to ensure that no spurious effect drives the remittance-mitigating effect. This test consists of re-estimating the regression as specified in equation 1, but over the period preceding the shock, meaning in planting 2018 and harvest 2019.

We hypothesize that the capital channel, including savings/credit, livestock, and rental earnings, is an essential mechanism through which the mitigating role of remittances may operate. Relying on savings represents the second most reported coping mechanism ${ }^{15}$ (29\% of households), highlighting the importance of savings as a coping strategy. Given the data evidence and literature findings suggesting that remittances can stimulate financial services (savings or credits) by relaxing household budgetary constraints (Anzoategui, Demirgüç-Kunt, and Pería, 2014; Ambrosius and Cuecuecha, 2016; Ajefu and Ogebe, 2019), we can reasonably expect that households leveraging remittances to access such financial capital are more able to smooth their consumption. Instead of using savings or asking for credit, rural households may rely on their assets as a coping mechanism (Nikoloski, Christiaensen, and Hill, 2018). As remittances release budgetary constraints, households are likely to buy more assets, such as livestock or equipment/land, generating rental earnings. Consequently, households with more capital are less likely to suffer from food insecurity during the COVID-19 shock. While $\beta_{1}$ captures the overall remittance mitigating effect, we propose to decompose this effect based on the access to capital to shed light on the capital mechanism. We investigate the capital mechanism formally using the following equations:

$$
y_{h t}=\tilde{\alpha}+\tilde{\beta}_{0} \text { shock }_{h} \times \text { post }_{t}+\sum_{j=1}^{3} \tilde{\beta}_{j} \text { shock }_{h} \times \text { post }_{t} \times \mathbb{1}_{\text {group }}=j+\tilde{\delta_{h}}+\tilde{\mu_{t}}+\epsilon_{h t}
$$

Where $j=0,1,2,3$ represents four subgroups of households. The first group represents the reference group and comprises households with no capital or remittances $(j=0)$. The coefficient $\tilde{\boldsymbol{\beta}_{0}}$ is expected to be positive $\left(\tilde{\boldsymbol{\beta}_{0}}>\mathbf{0}\right)$, as it captures the impact of the shock on households with no capital or remittances. This group is supposed to be the most vulnerable to the shock. The second group, which is our primary interest group, comprises households that simultaneously hold or access capital and receive remittances $(j=1)$. The coefficient associated with this latter group, i.e. $\tilde{\boldsymbol{\beta}_{1}}$, is the parameter that tests the capital mechanism hypothesis of the remittance mitigation effect:

$$
\tilde{\beta}_{1}=E\left[y_{h t} \mid \text { shock }_{h}=1, \text { post }_{t}=1, \mathbb{1}_{\{\text {group }=1\}}=1\right]-E\left[y_{h t} \mid \text { shock }_{h}=1, \text { post }_{t}=1, \mathbb{1}_{\{\text {group }=0\}}=1\right]
$$

The capital mechanism relies on the following hypothesis test: $\tilde{\boldsymbol{\beta}_{\mathbf{1}}}<\mathbf{0}$. The intuition is that the attenuating role of the remittances operates through the capital if accessing or holding capital amplifies its mitigating effect. In other words, the remittance mitigation effect is even higher when the household owns capital.

\footnotetext{
${ }^{15}$ Nigeria National Bureau of Statistics, The World Bank. 2020. COVID-19 impact monitoring, baseline report. https://microdata.worldbank.org/index.php/catalog/3712/download/48362
} 
The two following groups account for potential confounding mechanisms of the mitigating effect of remittances, different from the capital mechanism. The third group comprises households not-receiving remittances with capital $(j=2)$. The coefficient $\tilde{\boldsymbol{\beta}_{2}}$ captures potential mitigating effects related solely to the capital that are not related to remittances. Finally, the fourth group comprises households receiving remittances but with no capital $(j=3)$, to rule out other mechanisms contributing to the mitigation effect of remittances not operating through the capital. The coefficient associated with this group is $\tilde{\boldsymbol{\beta}_{\mathbf{3}}}$, assumed to be negative $\left(\tilde{\boldsymbol{\beta}_{\mathbf{3}}}<\mathbf{0}\right)$. $\tilde{\boldsymbol{\beta}_{\mathbf{3}}}$ captures the presence of other mechanisms driving the mitigation effect of remittances. For instance, households may use part of the remittances to buy inputs instead of investing in physical capital such as machinery. Household productivity may then increase so that when a shock occurs, they may be more able to better cope with the shock. The relationship between the parameters $\beta_{1}$ and $\tilde{\beta}_{i}, i=0,1,2,3$ is provided in Appendix A.

\section{Results}

\subsection{Overall mitigating effect of remittances during COVID-19 employment shock}

Table 3 shows the mitigating effect of remittances during COVID-19 employment shock on food insecurity. The results indicate that households that receive remittances experience less food insecurity. While the COVID-19 shock tends to increase the food insecurity score, remittances of any origin mitigate the shock's adverse effects (column 2). Food insecurity increases during the shock by 0.29 , for not-receiving households. However, the shock appears to be offset entirely or absorbed when the households receive remittances, as the food insecurity score is roughly zero for remittance beneficiaries (0.29-0.33). The literature on migration insurance tends to support significant remittance mitigation of this magnitude. For instance, Beuermann, Ruprah, and Sierra (2016) find similar magnitudes in Jamaica. Although interested in an entirely different shock, they indicate that remittances absorb $100 \%$ of an adverse health shock on household consumption. The remittance mitigation effect is also relatively sizable in the Philippines. Although interested in an entirely different shock, they indicate that remittances absorb a $100 \%$ of an adverse health shock on household consumption. The remittance mitigation effect is also relatively sizable in the Philipines. Yang and Choi (2007) find that International remittances replace $60 \%$ of the decline in household income resulting from rainfall shock. Furthermore, our findings highlight the heterogeneity of remittance mitigation effects regarding their origin. While Domestic remittances allow households to completely cover the adverse shock effect $(-0.29+0.29$; column 5$)$, the mitigating effect of International remittances absorbs the adverse shock effect and significantly exceeds it. The mitigating effect of International remittances is double that of Domestic remittances (columns 3, 4, and 5). The high average amount of remittances from overseas compared to those within-country might explain this.

Our results are in line with the global literature, especially regarding adverse shocks to food 
insecurity. There is evidence of an increase in food insecurity due to the COVID-19 shock in Kenya and Uganda, as well as in Nigeria. We find that overall, the shock increases the food insecurity score by 0.19 (column 1). This represents an increase of $25 \%$ in comparison with the baseline level (0.76), which is comparable to what has been found in the literature. Using the same data from Nigeria settings, Amare et al. (2020) findings show that lockdown increases the likelihood of running out of food by $26.8 \%$. Adjognon, Bloem, and Sanoh (2020) find that in instances of shock, food insecurity increases in the Mali urban area by approximately $20 \%$ compared with the baseline mean.

Although not studying the actual impact of the COVID-19 shock, Balde, Boly, and Avenyo (2020) investigate factors associated with the difficulty of meeting basic needs during the COVID-19 pandemic. Their results suggest that informal workers tend to experience more challenges in meeting their basic needs. However, their results suggest that informal workers receiving remittances are less likely to experience challenges in meeting their basic needs in Senegal, but not in Mali and Burkina Faso. Even though their results may suffer from sample representativeness issues, they provide suggestive evidence of the mitigating effect of remittances on COVID-19 shock in Senegal. In the Nigeria setting, Amare et al. (2020) study the differential impact of lockdown measures on various livelihoods, including remittances and assistance receiving. Their findings suggest a lower lockdown adverse effect on food insecurity in households that rely on remittances and government assistance. However, actual remittance mitigation effects cannot be disentangled because they pool remittances and government assistance.

Table 3: Remittances' mitigating effect

\begin{tabular}{|c|c|c|c|}
\hline $\begin{array}{l}\text { Dependent variable } \\
\text { Food insecurity score }\end{array}$ & (1) & $(2)$ & (3) \\
\hline Lockdown-due business closure & $\begin{array}{l}0.19^{* *} \\
(0.08)\end{array}$ & $\begin{array}{c}0.29^{* * *} \\
(0.10)\end{array}$ & $\begin{array}{c}0.29^{* * *} \\
(0.10)\end{array}$ \\
\hline $\begin{array}{l}\text { All remittances } 2018 / 2019 \\
\times \text { Lockdown-due business closure }\end{array}$ & - & $\begin{array}{c}-0.33^{* * *} \\
(0.12)\end{array}$ & - \\
\hline $\begin{array}{l}\text { International remittances } 2018 / 2019 \\
\times \text { Lockdown-due business closure }\end{array}$ & - & - & $\begin{array}{c}-0.69^{* * *} \\
(0.26)\end{array}$ \\
\hline $\begin{array}{l}\text { Domestic remittances } 2018 / 2019 \\
\times \text { Lockdown-due business closure }\end{array}$ & - & - & $\begin{array}{c}-0.29^{* *} \\
(0.13)\end{array}$ \\
\hline Time fixed effects & Yes & Yes & Yes \\
\hline $\begin{array}{l}\text { Household fixed effects } \\
\text { Constant }\end{array}$ & $\begin{array}{c}\text { Yes } \\
0.96^{* * *} \\
(0.02)\end{array}$ & $\begin{array}{c}\text { Yes } \\
0.96^{* * *} \\
(0.02)\end{array}$ & $\begin{array}{c}\text { Yes } \\
0.96^{* * *} \\
(0.02)\end{array}$ \\
\hline $\begin{array}{l}\text { Observations } \\
\text { Adjusted } R^{2}\end{array}$ & $\begin{array}{c}5850 \\
0.243\end{array}$ & $\begin{array}{r}5850 \\
0.245\end{array}$ & $\begin{array}{r}5850 \\
0.245\end{array}$ \\
\hline Food Insecurity Score Baseline Mean & & 0.76 & \\
\hline
\end{tabular}




\subsection{Heterogeneous effects}

The heterogeneous impact of the COVID-19 shock documented in the literature raises the question of whether the mitigation effect of remittances is also heterogeneous. The effect of the COVID-19 shock on food insecurity is notably higher among poor populations (Amare et al., 2020). In urban areas, the results depend on the context. Adjognon, Bloem, and Sanoh (2020) find a sharp increase in food insecurity in Bamako (Mali), Amare et al. (2020)) suggest no differential effect of the shock between urban and rural areas on food security. In other words, the impact of the shock on food insecurity is similar in rural and urban areas ${ }^{16}$, unlike in Mali. To examine this in Nigeria, we investigate the heterogeneity of remittance mitigation effects in both residential areas and across poverty dimensions.

Table 4 presents the heterogeneity of the mitigating effect of remittances on households by residence area. We operationalize the heterogeneity analysis with a triple interaction among the shock variables, remittance receiving, and household residence area. We consider households living in rural areas with no remittances as the reference group. Our results suggest a strong remittancemitigating effect in rural areas. Indeed, we find a significant overall increase in food insecurity among households in rural areas with no remittances (0.28; column 1). However, this adverse shock seems to be considerably attenuated by remittances in those areas $(-0.39$; column 1$)$. The cushioning effect of International remittances (-1.26; column 2), unsurprisingly, is higher than that of remittances originating within the country $(-0.32$; column 3$)$. Estimates fail to validate the mitigating effect of remittances in urban areas, except in Lagos, where we see a mitigating effect from International remittances.

The weak mitigating effect in urban areas is probably due to better underlying resilience or better access to other coping mechanisms that make these residents less reliant on remittances. For instance, market imperfections, such as credit constraints, are likely to be more pronounced in rural areas than in urban areas. Consequently, we can reasonably expect remittances to mitigate the shock impact in more financially constrained environments such as rural areas than in urban areas. Urban households are likely to access financial services, such as credit and savings, independent of remittances. They are then better able to smooth their consumption without relying on remittances. In contrast, in rural areas, credit constraints are pronounced, and households are expected to rely on remittances. Another reason for this weak mitigating effect may be the more stringent lockdown measures compared with rural areas, as the pandemic first started in large towns. Adjognon, Bloem, and Sanoh (2020) provides evidence of a significant decrease in human mobility in Bamako, Mali's capital, relative to rural areas following the lockdown. Given the intensity of mobility restrictions, households in urban areas may be exposed more to significant income losses, which may increase the likelihood of suffering from food insecurity.

Table 5 presents the heterogeneity results based on the poverty status measured in the 2018/2019 wave. We use the triple interaction among the shock, remittance status, and poverty status ${ }^{17}$ to

\footnotetext{
${ }^{16}$ We find similar results that we can provide upon request

${ }^{17}$ All the households in the two first consumption quintiles, which represent the $40 \%$ bottom consumption distribution, are considered as poor.
} 
Table 4: Remittances' mitigating effect : heterogeneity regarding residence area

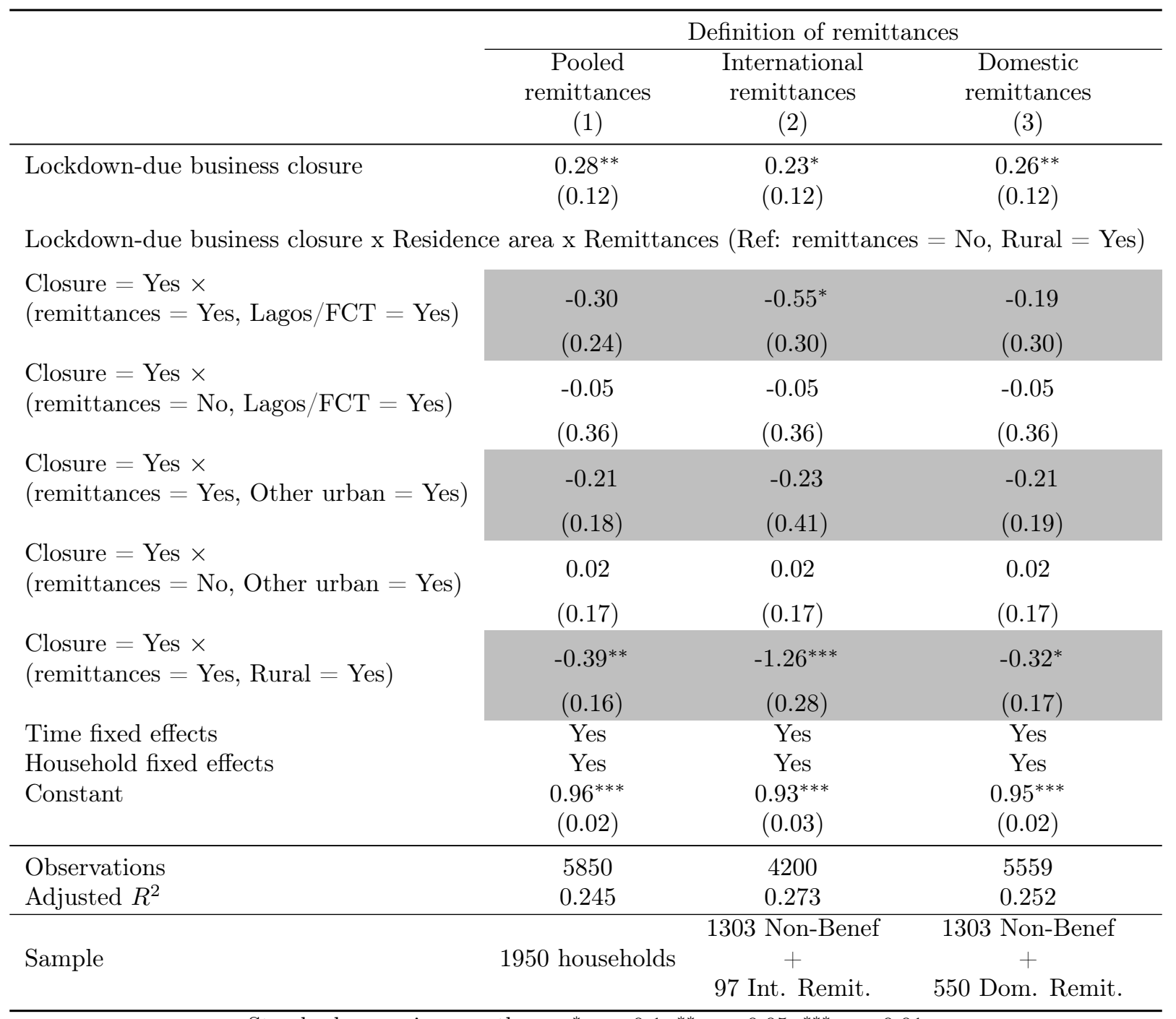

Standard errors in parentheses; ${ }^{*} p<0.1,{ }^{* *} p<0.05,{ }^{* * *} p<0.01$

+ FCT stands for Federal Capital Territory 
investigate the poverty differential effects of the mitigating role of remittances. Our reference group comprises poor households with no remittances. The results indicate that remittances can mitigate the negative effects of the shock, mainly for non-poor households. The pooled mitigating effect of remittances is estimated at -0.46 (column 1$)$. Consistent with the previous results, we find a larger mitigating effect of International remittances than Domestic remittances. Concerning poor households, we find evidence of mitigating effects only for remittances coming from abroad (-0.93; column 2). The Domestic remittance mitigation is almost zero. This indicates that Domestic remittances are likely to mitigate shocks only for better-off households. In contrast, International remittances can mitigate the negative consequences of a shock on food insecurity for the entire population.

Table 5: Remittances' mitigating effect: heterogeneity regarding poverty status in 2018/2019

\begin{tabular}{|c|c|c|c|}
\hline & \multicolumn{3}{|c|}{ Definition of remittances } \\
\hline & $\begin{array}{c}\text { Pooled } \\
\text { remittances } \\
(1)\end{array}$ & $\begin{array}{c}\text { International } \\
\text { remittances } \\
(2)\end{array}$ & $\begin{array}{c}\text { Domestic } \\
\text { remittances } \\
(3)\end{array}$ \\
\hline Lockdown-due business closure & $\begin{array}{l}0.36^{* *} \\
(0.14)\end{array}$ & $\begin{array}{l}0.31^{* *} \\
(0.14)\end{array}$ & $\begin{array}{l}0.34^{* *} \\
(0.14)\end{array}$ \\
\hline \multicolumn{4}{|c|}{ Lockdown-due business closure x Poor status $(2018 / 2019) \times$ Remittances $($ Ref: remittances $=$ No, $=$ Yes) } \\
\hline Closure $=$ Yes $\times($ remittances $=$ Yes, Poor $=$ Yes $)$ & $\begin{array}{l}-0.14 \\
(0.23)\end{array}$ & $\begin{array}{c}-0.93^{* * *} \\
(0.24)\end{array}$ & $\begin{array}{l}-0.08 \\
(0.24)\end{array}$ \\
\hline Closure $=$ Yes $\times($ remittances $=$ No, Poor $=$ Yes $)$ & $\begin{array}{l}-0.14 \\
(0.17)\end{array}$ & $\begin{array}{l}-0.14 \\
(0.17)\end{array}$ & $\begin{array}{l}-0.14 \\
(0.17)\end{array}$ \\
\hline Closure $=$ Yes $\times($ remittances $=$ Yes, Poor $=$ No $)$ & $\begin{array}{c}-0.46^{* * *} \\
(0.17)\end{array}$ & $\begin{array}{c}-0.73^{* *} \\
(0.31)\end{array}$ & $\begin{array}{c}-0.43^{* *} \\
(0.17)\end{array}$ \\
\hline Time fixed effects & Yes & Yes & Yes \\
\hline Household fixed effects & Yes & Yes & Yes \\
\hline Constant & $\begin{array}{c}0.96^{* * *} \\
(0.02)\end{array}$ & $\begin{array}{c}0.93^{* * *} \\
(0.03)\end{array}$ & $\begin{array}{c}0.95^{* * *} \\
(0.02)\end{array}$ \\
\hline Observations & 5850 & 4200 & 5559 \\
\hline Adjusted $R^{2}$ & 0.246 & 0.273 & 0.253 \\
\hline Sample & 1950 households & $\begin{array}{c}1303 \text { Non-Benef } \\
+ \\
97 \text { Int. Remit. }\end{array}$ & $\begin{array}{c}1303 \text { Non-Benef } \\
+ \\
550 \text { Dom. Remit. }\end{array}$ \\
\hline
\end{tabular}

Standard errors in parentheses; ${ }^{*} p<0.1,{ }^{* *} p<0.05,{ }^{* * *} p<0.01$

+ Households in the 1st and 2nd quintile of consumption are considered as poor.

\subsection{Robustness checks}

\subsection{Sensitivity of the estimates to both Shock and Food Insecurity definitions}

The primary shock definition used in this paper, lockdown-due business closure, is likely to capture a limited scope of the COVID-19 employment shock. It only captures the COVID-19 employment shock created by stringent restriction movement measures. However, COVID-19 may affect employment through the aforementioned "health channel" as well. A household member may get sick from COVID-19, causing he/she to stop working. To prevent themselves from getting sick, households 
may intentionally reduce their demand for goods/services requiring interpersonal contacts, resulting in business closures due to low demand. We test the robustness of our results by considering an alternative measure of the shock, that is, the number of confirmed COVID-19 cases by state. This measure of the shock is expected to capture the broad channels of the COVID-19 shock on employment. It measures household exposure to the pandemic and is generally used in the literature, for instance, by Amare et al. (2020).

Table 6 presents the effect of the mitigation of remittances during COVID-19 exposure on food insecurity. We adopt two definitions of COVID-19 exposure. First, COVID-19 exposure is measured by the number of confirmed cases (log scale) at the state level. Second, we measure the shock based on a dummy variable distinguishing high ${ }^{18}$ exposure to COVID-19 versus low exposure using the number of confirmed cases. Our results are consistent with previous estimates. Remittances can cushion the negative effects of COVID-19 shock. The mitigating effect is relatively higher for remittances coming from abroad than for those originating Domestically.

Table 6: Remittances' mitigating effect: robustness to shock definition

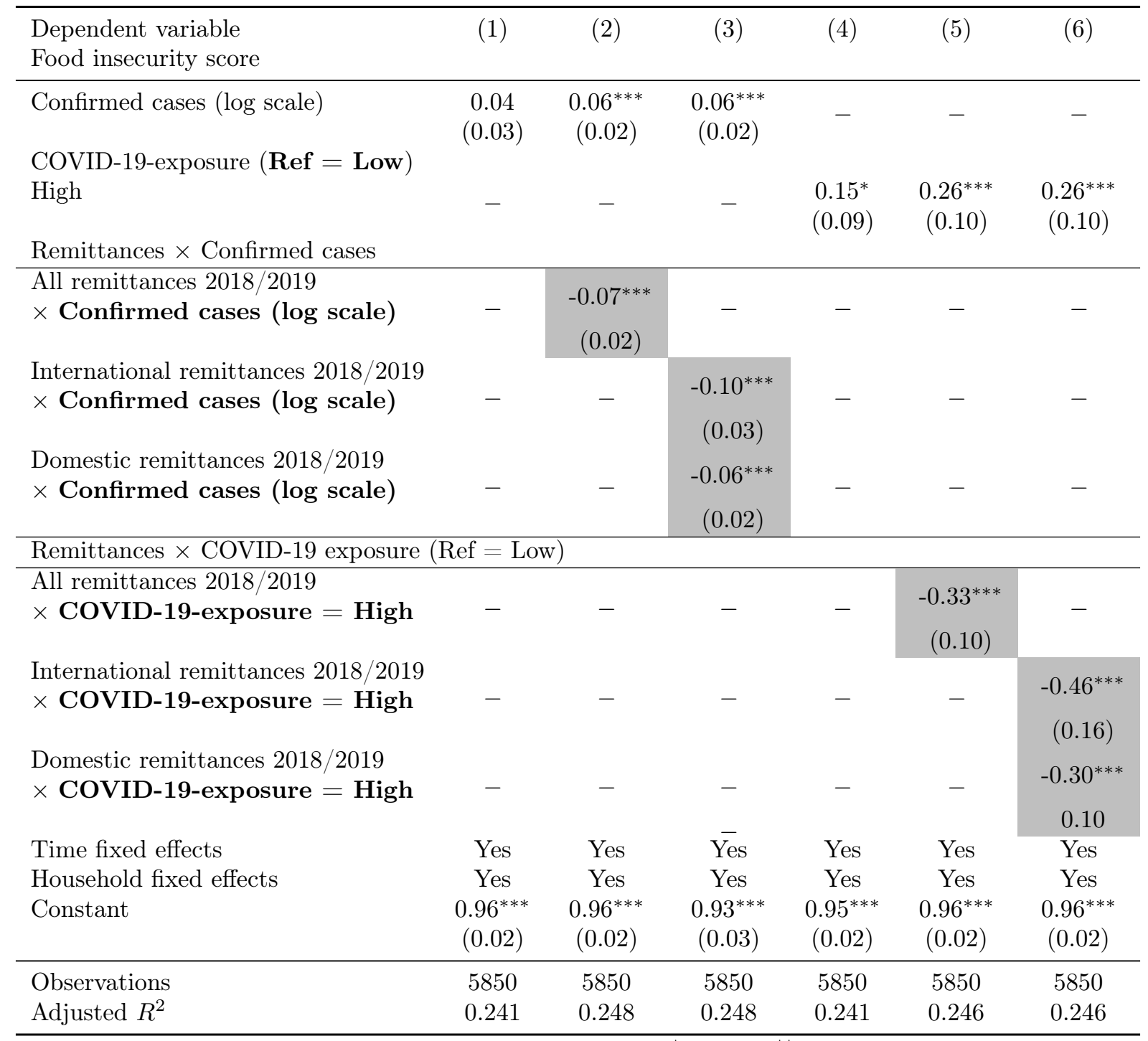

Robust Standard errors in parentheses; ${ }^{*} p<0.1,{ }^{* *} p<0.05$

\footnotetext{
${ }^{18}$ High COVID-19 exposure are states with a number of confirmed cases exceeding 62 cases (the median value).
} 
We complete our robustness checks using two sensitivity tests of our results. First, to ensure that our results are robust to the outcome definition (food insecurity), we proxy the food insecurity situation with the likelihood of skipping a meal, running out of food, or going the whole day without eating. Each of these three outcomes relates to the questions used to compute the food insecurity score. We estimate the mitigation effect of remittances on each of the three questions used to compute the food insecurity score (table B.6). ). Overall, our results remain qualitatively the same, suggesting the remittances' mitigating effect during the shock.

Second, we test the sensitivity of our results to the correction of attrition using sampling weights. We estimate the mitigation effect of remittances without adjusting the sampling weights. We estimate the remittances' mitigating effect without adjusting the sampling weights (table 7). The coefficients are roughly the same, although small differences in the expected direction are notable. We find that the magnitude of the remittance mitigation effect is slightly lower, in absolute value, than the weight-adjusted estimates (table 3). For instance, we find that the mitigating effect of International remittances is -0.60 (table 7 , column 5), when sampling weights are ignored, versus -0.69 , in the case where weights are accounted for (table 3 , column 5 ). This result suggests that the mitigating effect of remittances is likely to be downward-biased when attrition is not corrected, which is expected. Indeed, positive selection is likely to drive attrition, as previously highlighted. Table 11 indicates that higher-educated and wealthier households are more likely to be contacted and included in the post-COVID-19 survey sample. The mitigating effect is likely to be underestimated based on a sample of wealthier households because they are expected to be better able to cope with adverse shocks. Although our results seem robust regarding the correction of attrition, we could worry about potential unobservables. However, we are confident that the results remain unchanged given that our estimates represent a lower bound.

\subsection{Parallel trend and Placebo tests}

To confirm the mitigation effect of remittances, we test the plausibility of a parallel trend assumption and conduct a placebo test. The figure B.1 provides visual evidence of the plausibility of the common trend hypothesis. Before the COVID-19 shock occurred in May 2020, food insecurity in the two groups of countries seems to have evolved in tandem. We complete this visual comparison with regression analysis, including the impact of the shock on food insecurity in the period before May 2020. A statistically zero effect of the shock treatment (-0.02) is observed in this period, suggesting that the parallel trend assumption is plausible (table B.2). In addition to the parallel trend hypothesis, the placebo test tends to validate our estimations. The results of the placebo test are presented in Table 7. As expected, the shock has zero effect on food insecurity, and there is no evidence of remittance-mitigating effect across the diverse specifications.

\subsection{Persistence of the shock and remittances' mitigating effect}

Governments worldwide, including the Nigerian government, have enacted many social safety net programs to help households cope with COVID-19 negative consequences. This support may help 
Table 7: Remittances' mitigating effect: Robustness to sampling weights

\begin{tabular}{|c|c|c|c|}
\hline $\begin{array}{l}\text { Dependent variable } \\
\text { Food insecurity score }\end{array}$ & (1) & $(2)$ & $(3)$ \\
\hline Lockdown-due business closure & $\begin{array}{c}0.20^{* * *} \\
(0.06)\end{array}$ & $\begin{array}{c}0.30^{* * *} \\
(0.06)\end{array}$ & $\begin{array}{c}0.30^{* * *} \\
(0.06)\end{array}$ \\
\hline $\begin{array}{l}\text { All remittances } 2018 / 2019 \\
\times \text { Lockdown-due business closure }\end{array}$ & - & $\begin{array}{c}-0.30^{* * *} \\
(0.09)\end{array}$ & \\
\hline $\begin{array}{l}\text { International remittances } 2018 / 2019 \\
\times \text { Lockdown-due business closure }\end{array}$ & - & - & $\begin{array}{r}-0.60^{* * *} \\
(0.19)\end{array}$ \\
\hline $\begin{array}{l}\text { Domestic remittances } 2018 / 2019 \\
\times \text { Lockdown-due business closure }\end{array}$ & - & - & $\begin{array}{c}-0.25^{* *} \\
(0.10)\end{array}$ \\
\hline $\begin{array}{l}\text { Time fixed effects } \\
\text { Household fixed effects } \\
\text { Constant }\end{array}$ & $\begin{array}{c}\text { Yes } \\
\text { Yes } \\
0.89^{* * *} \\
(0.02)\end{array}$ & $\begin{array}{c}\text { Yes } \\
\text { Yes } \\
0.89^{* * *} \\
(0.02)\end{array}$ & $\begin{array}{c}\text { Yes } \\
\text { Yes } \\
0.89^{* * *} \\
(0.02)\end{array}$ \\
\hline $\begin{array}{l}\text { Observations } \\
\text { Adjusted } R^{2}\end{array}$ & $\begin{array}{r}5889 \\
0.238\end{array}$ & $\begin{array}{l}5889 \\
0.240\end{array}$ & $\begin{array}{r}5889 \\
0.241\end{array}$ \\
\hline
\end{tabular}

households recover their businesses. They also have eased movement restriction measures over time $^{19}$. Table B.5 shows a decrease in the incidence of shock over the period May to November 2020 from $37 \%$ to only $2 \%$. These subsequent measures may raise some identification issues. For instance, our estimates may be downward-biased because the impact of the shock could be more critical in the absence of these support programs. To avoid this potential identification problem, we primarily exploit the sample covering the period from planting 2018 to the early period (April-May 2020) of the COVID-19 shock (hereafter "short panel"). We assume that the relief program effects are limited to this period. For the first time, the government announced the delivery of up to 70,000 tons of grain on May 12, 2020. Furthermore, this period coincided with the highest level of movement restriction measures. ${ }^{20}$. Furthermore, this period coincides with the highest level of movement restriction measures.

We conduct a robustness check by expanding our sample (hereafter "extended panel") and include additional waves from June, August, and November 2020 (table 9). The results remain qualitatively consistent with previous findings based on the short panel (table 3). Employment shocks significantly increase household food insecurity, and remittances can mitigate this adverse effect. However, the magnitudes of the coefficients are lower in the extended panel. The impact of the shock on households with no remittances is lower, ranging from 0.19 to 0.26 , in comparison with the short panel estimates (coefficients vary from 0.20 to 0.30 ). The remittance mitigation effect is also lower in the extended panel. For instance, the magnitude of the mitigation of the pooled remittances is estimated at -0.22 in the extended panel (table 9) versus -0.30 in the short panel

\footnotetext{
${ }^{19}$ Based on Government announcements of early May, 2020: https://nairametrics.com/2020/04/27/fill-speech-ofpresident-buhari-on-covid-19-pandemic/

${ }^{20}$ https://www.ifpri.org/project/covid-19-policy-response-cpr-portal
} 
Table 8: Placebo test of the remittances' mitigating effect

\begin{tabular}{|c|c|c|c|}
\hline $\begin{array}{l}\text { Dependent variable } \\
\text { Food insecurity score }\end{array}$ & (1) & $(2)$ & $(3)$ \\
\hline Lockdown-due business closure & $\begin{array}{l}-0.02 \\
(0.08)\end{array}$ & $\begin{array}{l}-0.02 \\
(0.09)\end{array}$ & $\begin{array}{l}-0.02 \\
(0.09)\end{array}$ \\
\hline $\begin{array}{l}\text { All remittances } 2018 / 2019 \\
\times \text { Lockdown-due business closure }\end{array}$ & - & $\begin{array}{l}-0.01 \\
(0.13)\end{array}$ & - \\
\hline $\begin{array}{l}\text { International remittances } 2018 / 2019 \\
\times \text { Lockdown-due business closure }\end{array}$ & - & - & $\begin{array}{l}-0.56 \\
(0.34)\end{array}$ \\
\hline $\begin{array}{l}\text { Domestic remittances } 2018 / 2019 \\
\times \text { Lockdown-due business closure }\end{array}$ & - & - & $\begin{array}{r}0.06 \\
(0.14)\end{array}$ \\
\hline $\begin{array}{l}\text { Time fixed effects } \\
\text { Household fixed effects } \\
\text { Constant }\end{array}$ & $\begin{array}{c}\text { Yes } \\
\text { Yes } \\
0.96^{* * *} \\
(0.02)\end{array}$ & $\begin{array}{c}\text { Yes } \\
\text { Yes } \\
0.96^{* * *} \\
(0.02) \\
\end{array}$ & $\begin{array}{c}\text { Yes } \\
\text { Yes } \\
0.96^{* * *} \\
(0.02) \\
\end{array}$ \\
\hline $\begin{array}{l}\text { Observations } \\
\text { Adjusted } R^{2}\end{array}$ & $\begin{array}{l}3926 \\
0.108\end{array}$ & $\begin{array}{l}3900 \\
0.097\end{array}$ & $\begin{array}{l}3900 \\
0.100\end{array}$ \\
\hline
\end{tabular}

(table 3). ). While these results may suggest a potential downward bias in our estimates due to government relief programs, the results remain unchanged overall ${ }^{21}$. Notably, the results ensure that our strategy focuses on the impact in the early period of the shock, which is the first round of the COVID-19 survey in May 2020.

The extended panel sample offers the opportunity to investigate the persistence of the COVID-19 employment shock over time and the lasting mitigation effect of remittances. Figure 3 shows the regression coefficients estimating the impacts of the shock and remittance mitigation effect over time. The results suggest that the negative shock effects are likely to persist over the considered period, while the mitigating role of the remittances seems effective in the early stages of the shock. We find that the COVID-19 employment shock increases food insecurity in May 2020 (time = 0) and remains significantly high over the following periods from June 2020 (time $=1$ ) to November 2020 (time $=3$ ). The remittances appear to significantly cushion the shock's adverse effect during the three rounds from May 2020 (time $=0$ ) to August 2020 (time =2). In November 2020, the remittance mitigation effect became insignificant, while the shock's adverse effect persisted over the entire period (from time $=0$ to time $=3$ ). The downward pattern of remittance mitigation is expected because household capital, especially savings, may be insufficient to hold in the long run. Indeed, household savings are likely to decline over time because of the employment shock, preventing the renewal of savings stock.

\footnotetext{
${ }^{21}$ All estimates with the extended panel are unweighted and are more likely to be subject to attrition bias. Hence, results must be taken with caution and can provide only suggestive evidence
} 
Table 9: Remittances mitigating effect (extended panel)

\begin{tabular}{lccc}
\hline $\begin{array}{l}\text { Dependent variable } \\
\text { Food insecurity score }\end{array}$ & $(1)$ & $(2)$ & $(3)$ \\
\hline Lockdown-due business closure & $0.19^{* * *}$ & $0.26^{* * *}$ & $0.26^{* * *}$ \\
& $(0.05)$ & $(0.06)$ & $(0.06)$ \\
All remittances $2018 / 2019$ & & $-0.22^{* * *}$ & - \\
$\times$ Lockdown-due business closure & - & $(0.08)$ & - \\
& - & & $-0.42^{* *}$ \\
International remittances 2018/2019 & - & - & $(0.17)$ \\
$\times$ Lockdown-due business closure & - & - & $-0.19^{* *}$ \\
& - & - & $(0.09)$ \\
Domestic remittances 2018/2019 & - & & Yes \\
$\times$ Lockdown-due business closure & & Yes & Yes \\
& Yes & Yes & $0.88^{* * *}$ \\
Time fixed effects & Yes & $0.02)$ \\
Household fixed effects & $0.88^{* * *}$ & $0.88^{* * *}$ & 11213 \\
Constant & $(0.02)$ & $(0.02)$ & 0.186 \\
& 11213 & 11213 & \\
\hline Observations & 0.185 & 0.186 & \\
Adjusted $R^{2}$ &
\end{tabular}

Robust Standard errors in parentheses; ${ }^{*} p<0.1,{ }^{* *} p<0.05$

$*$ The sample includes the additional waves of June, August and November 2020 rounds

** Estimates are unweighted.

Figure 3: Lasting effects of shock and remittances' mitigating role over time

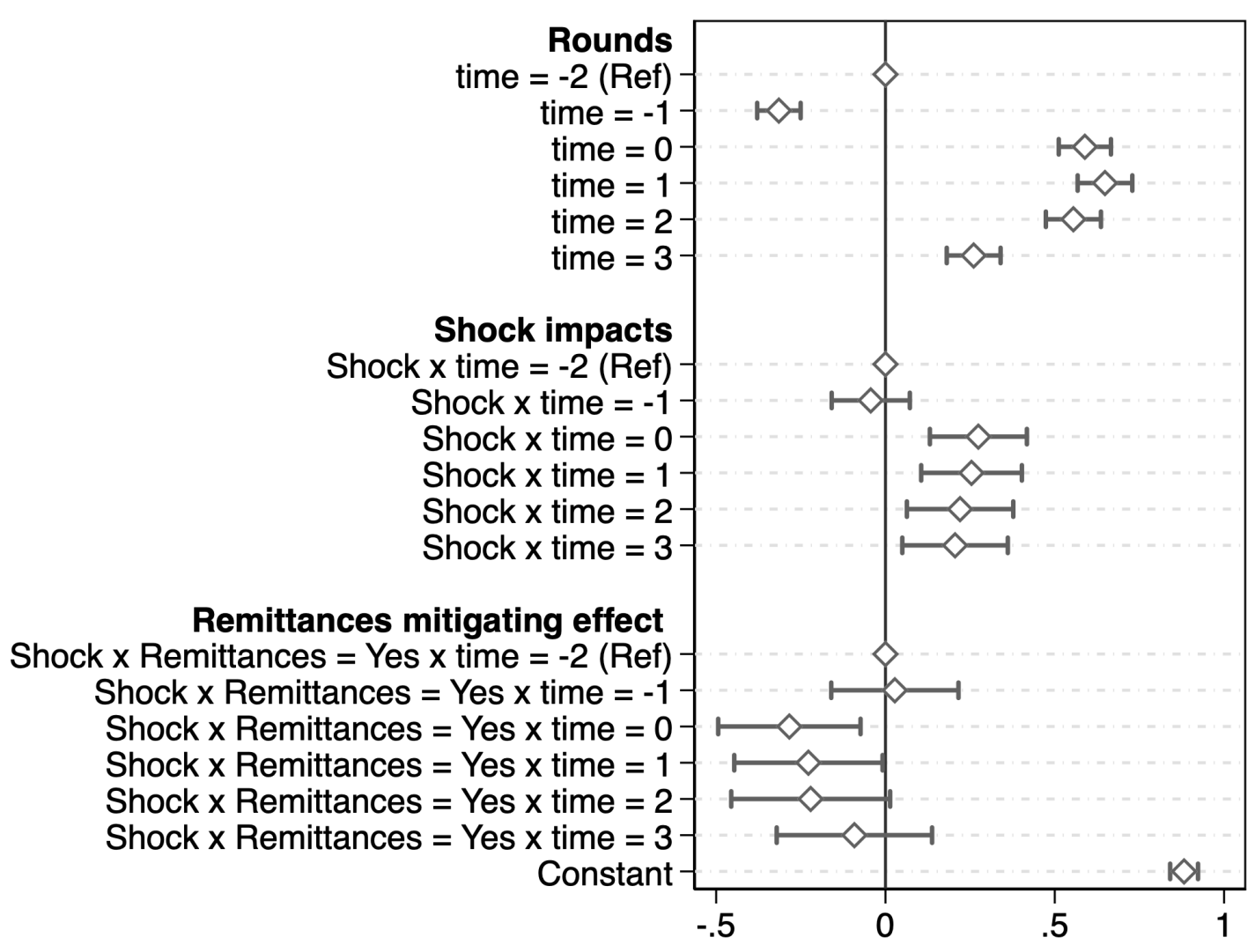

Source: GHS wave 4 (2018/2019), COVID-19 NLPS 2020, Authors' calculations.

* The sample includes the additional waves of June, August and November 2020 rounds.

** Confident Intervals are estimated at $95 \%$ level 


\subsection{Capital mechanism test}

The capital mechanism is tested by considering the broad definitions of household capital, including three dimensions. The first dimension dimension is the ownership of an account in a financial institution. We assume that households holding an account in a financial institution ${ }^{22}$ are likely to access formal financial services such as savings or financial credits that make them less capitalconstrained. Subsequently, they are likely to smooth their consumption through access to such services compared with households with no formal financial services. The second dimension is informal financial services through participation in rotating savings and credit association. The third dimension of capital is ownership of livestock or rental earnings. Indeed, households may hold capital in forms other than money or may even receive non-labor income, which may prevent them from facing food insecurity. For instance, households may hold assets such as livestock that they can sell or consume at the time of the COVID-19 shock. Some households may earn non-labor income from land or other productive assets (tractors, trailers, etc.) that they rent out.

Table 10 presents the capital mechanism hypothesis test results based on 3. The findings support the assumption that capital represents a channel through which the mitigating effect of the remittances can operate. The remittance mitigation effect appears to be amplified when households have access to any form of the considered capital (-0.44; column 1$)$. The capital mechanism seems to be driven mainly by formal financial inclusion, defined as having an account in a financial institution, livestock ownership, or rental earnings. The interaction effect of informal capital and remittances is insignificant, failing to validate the capital hypothesis mechanism for this type of capital. The capital mechanism hypothesis remains consistent when considering the remittances' origins (tables B.3). Overall, the results indicate that the cushioning effects of both International and Domestic remittances are higher for households with access to or those holding capital.

The other interaction coefficients consistently support the savings amplifying effect of the mitigating role of remittances. The coefficients associated with the group of remittance recipient households with no capital or those with a negative expected sign are not significant. In other words, recipient households with no capital appear to be unable to cope with the shock. This result may suggest that households fail to properly smooth their consumption when remittances do not contribute to reinforcing household capital. Similarly, households with capital, but not receiving remittances, seem unable to significantly mitigate the shock's negative consequences. This may indicate that the capital held by these households is insufficient to mitigate the shock.

The literature points out the differential impact of the shock according to the activity sector, which may raise some identification concerns. Wage workers seem to be less affected by the COVID19 shock and lockdown measures (Adams-Prassl et al., 2020; Balde, Boly, and Avenyo, 2020; Amare et al., 2020). One potential explanation is that wage workers, especially those working in the formal sector, may continue to receive their salary even during the pandemic when businesses are shut down. Wage related activities are also likely to be operated remotely. In Nigeria, Amare et al. (2020) find that most wage workers are employed in the public sector and non-governmental organizations.

\footnotetext{
${ }^{22}$ Commercial bank, micro-finance institution, cooperative society
} 
Table 10: Capital channel hypothesis test of pooled remittances' mitigating effect

\begin{tabular}{|c|c|c|c|c|}
\hline & \multicolumn{4}{|c|}{ Definition of the capital } \\
\hline & $\begin{array}{l}\text { Pooled } \\
\text { capital } \\
(1)\end{array}$ & $\begin{array}{c}\text { Formal } \\
\text { Financial } \\
\text { Services } \\
(2)\end{array}$ & $\begin{array}{c}\text { Informal } \\
\text { Financial } \\
\text { Services } \\
(3)\end{array}$ & $\begin{array}{c}\text { Livestock } \\
\text { ownership, } \\
\text { Rental } \\
\text { earnings } \\
(4)\end{array}$ \\
\hline Lockdown-due business closure & $\begin{array}{l}0.40^{*} \\
(0.22)\end{array}$ & $\begin{array}{c}0.48^{* *} \\
(0.22)\end{array}$ & $\begin{array}{l}0.44^{*} \\
(0.22)\end{array}$ & $\begin{array}{c}0.49^{* *} \\
(0.23)\end{array}$ \\
\hline \multicolumn{5}{|c|}{ Lockdown-due business closure x Capital group $($ Ref: Capital $=$ No, remittances $=$ No $)$} \\
\hline Closure $=$ Yes $\times($ Capital $=$ Yes, remittances $=$ Yes $)$ & $\begin{array}{c}-0.44^{*} \\
(0.23)\end{array}$ & $\begin{array}{c}-0.54^{* *} \\
(0.24)\end{array}$ & $\begin{array}{l}-0.10 \\
(0.26)\end{array}$ & $\begin{array}{c}-0.91^{* * *} \\
(0.27)\end{array}$ \\
\hline Closure $=$ Yes $\times($ Capital $=$ Yes, remittances $=$ No $)$ & $\begin{array}{l}-0.15 \\
(0.23)\end{array}$ & $\begin{array}{l}-0.26 \\
(0.24)\end{array}$ & $\begin{array}{c}0.01 \\
(0.24)\end{array}$ & $\begin{array}{l}-0.03 \\
(0.29)\end{array}$ \\
\hline Closure $=$ Yes $\times($ Capital $=$ No, remittances $=$ Yes $)$ & $\begin{array}{l}-0.39 \\
(0.38)\end{array}$ & $\begin{array}{l}-0.39 \\
(0.38)\end{array}$ & $\begin{array}{c}-0.39 \\
(0.38)\end{array}$ & $\begin{array}{l}-0.39 \\
(0.38)\end{array}$ \\
\hline Time fixed effects & Yes & Yes & Yes & Yes \\
\hline Household fixed effects & Yes & Yes & Yes & Yes \\
\hline Constant & $\begin{array}{c}0.96^{* * *} \\
(0.02)\end{array}$ & $\begin{array}{c}0.97^{* * *} \\
(0.03)\end{array}$ & $\begin{array}{c}0.92^{* * *} \\
(0.03)\end{array}$ & $\begin{array}{c}1.02^{* * *} \\
(0.04)\end{array}$ \\
\hline Observations & 5850 & 4671 & 3132 & 1995 \\
\hline Adjusted $R^{2}$ & 0.245 & 0.213 & 0.253 & 0.217 \\
\hline
\end{tabular}

Such individuals tend to have long-run contracts, which enables easier access to financial services, such as savings or credit, and subsequently, more capital. Evidence in the literature also indicates that farmers are less likely to experience deterioration in food security in comparison with other sectors(Kansiime et al., 2020), mostly because farmers rely less on market sources for food. The correlation between these underlying factors of employment and capital may represent confounding factors for the mitigating mechanism of capital through remittances.

We test the robustness of the capital mechanism by controlling for employment activity heterogeneity prior to COVID-19 (table 11). We revisit the capital mechanism test by interacting the time variable with three dummies capturing household employment activities during the harvest 2019 period. The coefficients associated with the capital mechanism test decrease when accounting for employment heterogeneity. The interaction effect between capital and remittances declines by approximately 0.05 . This may suggest a potential upward bias in the capital mechanism test if the employment heterogeneity trend is not accounted for. As anticipated, this decline in the coefficients seems to be driven by wage employment. However, the findings remain robust, validating the capital mechanism test. 
Table 11: Capital channel hypothesis test of pooled remittances' mitigating effect: Robustness to control for employment activities

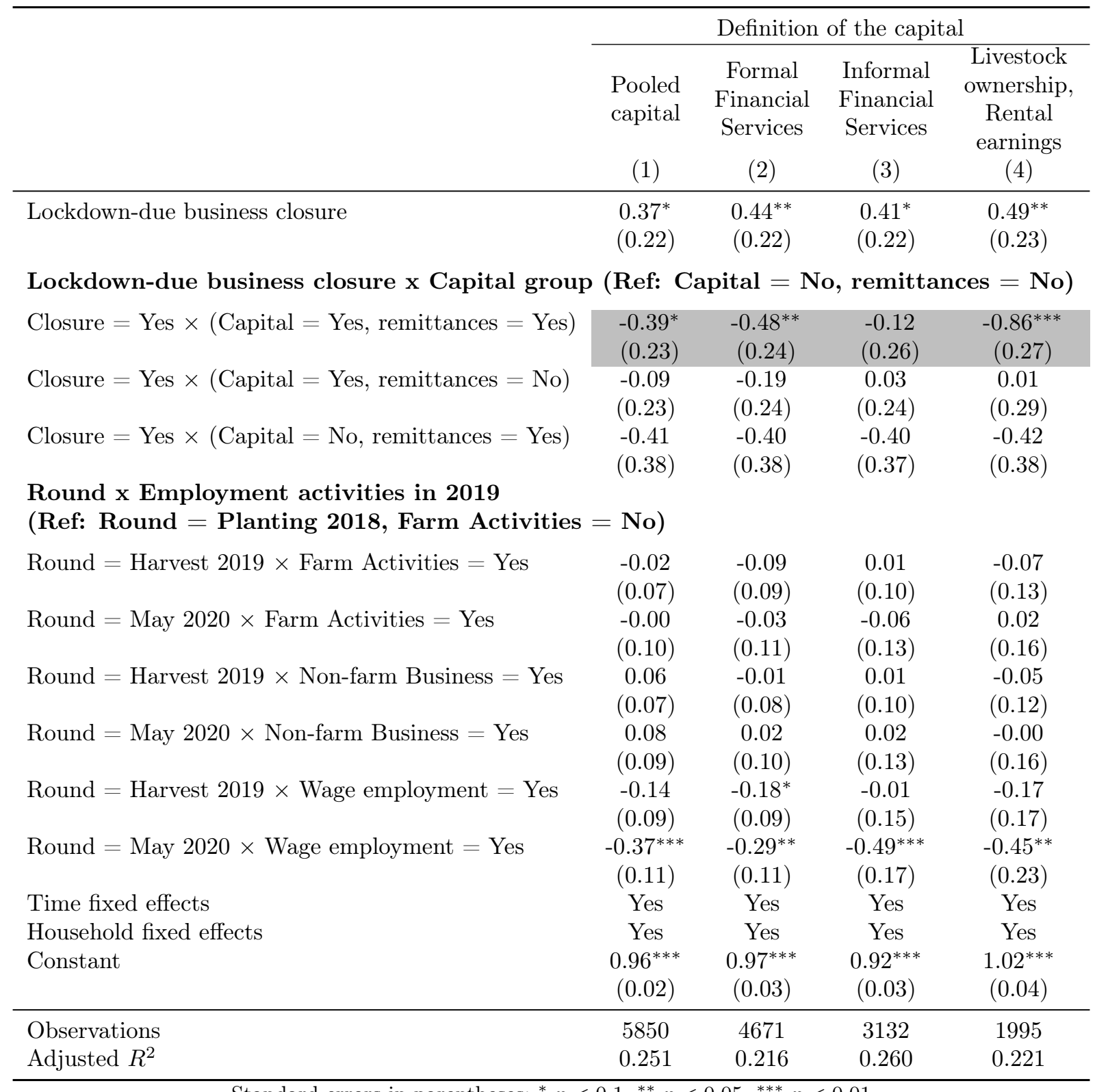

Standard errors in parentheses; ${ }^{*} p<0.1,{ }^{* *} p<0.05,{ }^{* * *} p<0.01$ 


\section{Conclusion}

This study assesses the mitigation effect of remittances during the COVID-19 employment shock on Nigeria's food insecurity. Combining pre-COVID-19 and post-COVID-19 data, we implement the DID approach to assess the cushioning impact of remittances. The results indicate that remittances are mitigating adverse COVID-19 employment shocks, especially in the short run. Remittances beneficiary households appear to experience significantly lower deterioration in their food security at the early stages of the shock. The findings also highlight some heterogeneity regarding the origin of remittances. Overall, the mitigating effect is higher for remittances coming from abroad than for those originating Domestically. Furthermore, the mitigating effect of remittances appears to have the greatest impact on rural households and those that are non-poor. Concerning urban and poor populations, we find that only International remittances are cushioning the adverse shock to food insecurity. Interestingly, we find evidence that the mitigating effect is likely to operate through the capital mechanism. The remittance mitigation effect seems amplified when the household holds a bank account in a financial institution and capital in the form of livestock or rental earnings.

Our results highlight the crucial role that remittances play in mitigating the adverse consequences of a shock of magnitude such as that of the COVID-19 pandemic, especially in the early stages. Before the government enacts relief measures, remittances help households cope with the shock through the capital mechanism. This result is striking because remittances have not been predicted to play a role during the COVID-19 pandemic, as they are expected to decrease sharply owing to the pandemic outbreak in migration destination countries. Consequently, our findings have the important policy implication that remittances may still represent a vital insurance source worth considering, especially in the post-pandemic context. Governments worldwide, along with the international community, are likely to rethink and revise national social protection strategies to provide more support to households and increase their resilience to adverse shocks. These strategies should include measures that incentivize remittance recipient households to channel them toward increasing household capital. Furthermore, remittance-provided protection should be considered complementary to existing social protection systems. Our findings support that remittances are likely to protect only a part of the population, mainly rural and non-poor households.

This paper has some limitations that pave the way for further investigations. We focus mainly on past remittances because our primary aim is to shed light on the ex-ante mechanism through the capital channel. However, remittances received during the shock, although lower than usual circumstances, may potentially help households cope with shock and contribute to the recovery and rebuilding required following the COVID-19 pandemic. For identification purposes, this raises challenges beyond this paper's scope. We leave this issue for future research. 


\section{References}

Adams-Prassl, Abi, Teodora Boneva, Marta Golin, and Christopher Rauh. 2020. "Inequality in the impact of the coronavirus shock: Evidence from real time surveys." Journal of Public Economics 189:104245. URL http://www.sciencedirect.com/science/article/pii/ S0047272720301092.

Adjognon, Guigonan Serge, Jeffrey R. Bloem, and Aly Sanoh. 2020. "The Coronavirus Pandemic and Food Security : Evidence from West Africa." Tech. Rep. 9474, The World Bank. URL https:// ideas.repec.org/p/wbk/wbrwps/9474.html. Publication Title: Policy Research Working Paper Series.

Ajefu, Joseph Boniface and Joseph O. Ogebe. 2019. "Migrant remittances and financial inclusion among households in Nigeria." Oxford Development Studies 47 (3):319-335. URL https://doi. org/10.1080/13600818.2019.1575349.

Akim, Al-Mouksit. 2018. Trois essais sur la migration, les transferts privés et le développement économique en Afrique Subsaharienne. PhD Thesis, Université Paris Dauphine - PSL Research University; Université Cheikh Anta Diop de Dakar.

Akim, Al-mouksit and Firmin Ayivodji. 2020. "Interaction effect of lockdown with economic and fiscal measures against COVID-19 on social-distancing compliance: Evidence from Africa." Available at SSRN 3621693.

Amare, Mulubrhan, Kibrom A. Abay, Luca Tiberti, and Jordan Chamberlin. 2020. Impacts of Covid-19 on food security: panel data evidence from Nigeria, vol. 1956. Intl Food Policy Res Inst.

Ambrosius, Christian and Alfredo Cuecuecha. 2013. "Are Remittances a Substitute for Credit? Carrying the Financial Burden of Health Shocks in National and Transnational Households." World Development 46:143 - 152. URL http://www.sciencedirect.com/science/article/ pii/S0305750X13000387.

. 2016. "Remittances and the Use of Formal and Informal Financial Services." World Development 77:80 - 98. URL http://www.sciencedirect.com/science/article/pii/ S0305750X15001916.

Amuedo-Dorantes, Catalina and Susan Pozo. 2011. "Remittances and Income Smoothing." The American Economic Review 101 (3):582-587. URL http://www.jstor.org/stable/29783810.

Anzoategui, Diego, Asli Demirgüç-Kunt, and María Soledad Martínez Pería. 2014. "Remittances and Financial Inclusion: Evidence from El Salvador." World Development 54:338 - 349. URL http://www.sciencedirect.com/science/article/pii/S0305750X13002180.

Arezki Rabah, Boly Amadou and Amah Koffi. 2021. "African Economic Outlook 2021: From Debt Resolution to Growth: The road Ahead for Africa." African development bank report, African Development Bank. 
Balde, Racky, Mohamed Boly, and Elvis Avenyo. 2020. "Labour market effects of COVID-19 in subSaharan Africa: An informality lens from Burkina Faso, Mali and Senegal." MERIT Working Papers 2020-022, United Nations University - Maastricht Economic and Social Research Institute on Innovation and Technology (MERIT). URL https://EconPapers.repec.org/RePEc:unm: unumer : 2020022.

Bargain, Olivier and Ulugbek Aminjonov. 2020a. "Poverty and COVID-19 in Developing Countries." Tech. Rep. 2020-08, Groupe de Recherche en Economie Théorique et Appliquée (GREThA). URL https://ideas.repec.org/p/grt/bdxewp/2020-08.html. Publication Title: Bordeaux Economics Working Papers.

- 2020b. "Trust and compliance to public health policies in times of COVID-19." Journal of Public Economics 192:104316. URL http://www.sciencedirect.com/science/article/pii/ S0047272720301808.

Beaton, Kimberly, Serhan Cevik, and Seyed Reza Yousefi. 2018. "Smooth operator: remittances and household consumption during fiscal shocks." The BE Journal of Macroeconomics 18 (2). Publisher: De Gruyter.

Beuermann, Diether W., Inder J. Ruprah, and Ricardo E. Sierra. 2016. "Do remittances help smooth consumption during health shocks?: Evidence from Jamaica." The Journal of Developing Areas $50(3): 1-19$.

Combes, Jean-Louis and Christian Ebeke. 2011. "Remittances and household consumption instability in developing countries." World Development 39 (7):1076-1089. URL http://www. sciencedirect.com/science/article/pii/S0305750X10002287.

David, Antonio C. 2011. "How do international financial flows to developing countries respond to natural disasters?" Global Economy Journal 11 (4).

Demirgüç-Kunt, Asli. 2014. "Global financial development report." In Global financial development report. Washington DC: World Bank, 1-224.

Fafchamps, Marcel, Christopher Udry, and Katherine Czukas. 1998. "Drought and saving in West Africa: are livestock a buffer stock?" Journal of Development economics 55 (2):273-305. Publisher: Elsevier.

Freije-Rodriguez, Samuel and Michael Woolcock. 2020. Poverty and Shared Prosperity 2020. World Bank, Washington DC. URL https://www.worldbank.org/en/publication/ poverty-and-shared-prosperity.

Gubert, Flore. 2002. "Do migrants insure those who stay behind? Evidence from the Kayes area (Western Mali)." Oxford Development Studies 30 (3):267-287.

Kansiime, Monica K., Justice A. Tambo, Idah Mugambi, Mary Bundi, Augustine Kara, and Charles Owuor. 2020. "COVID-19 implications on household income and food security in Kenya and Uganda: Findings from a rapid assessment.” World development 137:105199. Publisher: Elsevier. 
Korinek, Anton, Johan A. Mistiaen, and Martin Ravallion. 2007. "An econometric method of correcting for unit nonresponse bias in surveys." Journal of Econometrics 136 (1):213-235. URL https://www.sciencedirect.com/science/article/pii/S0304407606000327.

Lara, Jaime. 2016. "Remittances as an Insurance Mechanism in the Labor Market." Journal of Labor Research 37 (3):368-387.

Mondal, Ripon Kumar and Rasheda Khanam. 2018. "The impacts of international migrants' remittances on household consumption volatility in developing countries." Economic Analysis and Policy 59:171-187. Publisher: Elsevier.

NBS and WB. 2020. "Nigeria COVID-19 National Longitudinal Phone Survey (COVID-19 NLPS) Baseline."

Nikoloski, Zlatko, Luc Christiaensen, and Ruth Hill. 2018. "Household shocks and coping mechanism: evidence from Sub-Saharan Africa." Publisher: World Bank .

Odozi, John Chiwuzulum, Timothy Taiwo Awoyemi, and Bolarin Titus Omonona. 2010. "Household poverty and inequality: the implication of migrants' remittances in Nigeria." Journal of Economic Policy Reform 13 (2):191-199. URL https://doi.org/10.1080/17487871003700788.

Pereira, Marcos and Ana Marlucia Oliveira. 2020. "Poverty and food insecurity may increase as the threat of COVID-19 spreads." Public Health Nutrition 23 (17):3236-3240. Publisher: Cambridge University Press.

Ratha, Dilip K., Supriyo De, Eung Ju Kim, and Nadege Desiree Yameogo. 2020. "Phase II: COVID19 crisis through a migration lens." Migration and Development Brief 33.

Wooldridge, Jeffrey M. 2007. "Inverse probability weighted estimation for general missing data problems." Journal of Econometrics 141 (2):1281-1301. URL https://www.sciencedirect. com/science/article/pii/S0304407607000437.

Wren-Lewis, Simon. 2020. "The Economic Effects of a Pandemic." In Economics in the Time of COVID-19. Baldwin, R. and Weder di Mauro, B., cepr press ed., 109-112.

Yang, Dean and HwaJung Choi. 2007. "Are remittances insurance? Evidence from rainfall shocks in the Philippines." The World Bank Economic Review 21 (2):219-248. URL http://wber. oxfordjournals.org/content/21/2/219. short. 


\section{Appendix}

\section{A. Identification of the interest parameter $\beta_{1}$}

From the equation 1, we have the following expressions :

$$
\begin{aligned}
& E\left[y_{h t} \mid \text { shock }_{h}=1, \text { post }_{t}=1, \mathbb{1}_{\text {remittances }_{h}}=1\right]=\alpha+\beta_{0}+\beta_{1}+\delta_{h}+\mu_{t} \\
& E\left[y_{h t} \mid \text { shock }_{h}=1, \text { post }_{t}=1, \mathbb{1}_{\text {remittances }_{h}}=0\right]=\alpha+\beta_{0}+\delta_{h}+\mu_{t}
\end{aligned}
$$

$\hat{\beta}_{1}$ is the estimator of:

$$
\beta_{1}=E\left[y_{h t} \mid \text { shock }_{h}=1, \text { post }_{t}=1, \mathbb{1}_{\text {remittances }_{h}}=1\right]-E\left[y_{h t} \mid \text { shock }_{h}=1, \text { post }_{t}=1, \mathbb{1}_{\text {remittances }_{h}}=0\right]
$$

Using equation 3 , we get the following decomposition :

$$
\begin{aligned}
& E\left[y_{h t} \mid \text { shock }_{h}=0, \text { post }_{t}=0, \mathbb{1}_{\{\text {group }=0\}}=1\right]=\tilde{\alpha}+\tilde{\delta_{h}}+\tilde{\mu_{t}} \\
& E\left[y_{h t} \mid \text { shock }_{h}=1, \text { post }_{t}=1, \mathbb{1}_{\{\text {group }=0\}}=1\right]=\tilde{\alpha}+\tilde{\beta_{0}}+\tilde{\delta_{h}}+\tilde{\mu_{t}} \\
& E\left[y_{h t} \mid \text { shock }_{h}=1, \text { post }_{t}=1, \mathbb{1}_{\{\text {group }=1\}}=1\right]=\tilde{\alpha}+\tilde{\beta_{0}}+\tilde{\beta_{1}}+\tilde{\delta_{h}}+\tilde{\mu_{t}} \\
& E\left[y_{h t} \mid \text { shock }_{h}=1, \text { post }_{t}=1, \mathbb{1}_{\{\text {group }=2\}}=1\right]=\tilde{\alpha}+\tilde{\beta_{0}}+\tilde{\beta_{2}}+\tilde{\delta_{h}}+\tilde{\mu_{t}} \\
& E\left[y_{h t} \mid \text { shock }_{h}=1, \text { post }_{t}=1, \mathbb{1}_{\{\text {group=3\} }}=1\right]=\tilde{\alpha}+\tilde{\beta_{0}}+\tilde{\beta_{3}}+\tilde{\delta_{h}}+\tilde{\mu_{t}}
\end{aligned}
$$

The following decomposition gives the expressions of parameters $\tilde{\beta}_{0}, \tilde{\beta}_{1}, \tilde{\beta}_{2}$, and $\tilde{\beta}_{3}$ in population:

$$
\begin{aligned}
& \tilde{\beta}_{0}=E\left[y_{h t} \mid \text { shock }_{h}=1, \text { post }_{t}=1, \mathbb{1}_{\text {\{group=0\} }}=1\right]-E\left[y_{h t} \mid \text { shock }_{h}=0, \text { post }_{t}=0, \mathbb{1}_{\text {group }=0\}}=1\right] \\
& \tilde{\beta}_{1}=E\left[y_{h t} \mid \text { shock }_{h}=1, \text { post }_{t}=1, \mathbb{1}_{\text {group }=1\}}=1\right]-E\left[y_{h t} \mid \text { shock }_{h}=1, \text { post }_{t}=1, \mathbb{1}_{\{\text {group }=0\}}=1\right] \\
& \tilde{\beta}_{2}=E\left[y_{h t} \mid \text { shock }_{h}=1, \text { post }_{t}=1, \mathbb{1}_{\text {group }=2\}}=1\right]-E\left[y_{h t} \mid \text { shock }_{h}=1, \text { post }_{t}=1, \mathbb{1}_{\{\text {group }=0\}}=1\right] \\
& \tilde{\beta}_{3}=E\left[y_{h t} \mid \text { shock }_{h}=1, \text { post }_{t}=1, \mathbb{1}_{\{\text {group }=3\}}=1\right]-E\left[y_{h t} \mid \text { shock }_{h}=1, \text { post }_{t}=1, \mathbb{1}_{\text {group }=0\}}=1\right]
\end{aligned}
$$

Suppose that:

$$
\begin{aligned}
& E_{1}=\left(\text { shock }_{h}=1, \text { post }_{t}=1, \mathbb{1}_{\text {remittances }_{h}}=1\right) \\
& E_{0}=\left(\text { shock }_{h}=1, \text { post }_{t}=1, \mathbb{1}_{\text {remittances }_{h}}=0\right)
\end{aligned}
$$

Using the below equations for event $E_{1}$ n we have :

$$
\begin{gathered}
E\left[y_{h t} \mid E_{1}\right]=E\left[y_{h t} \mid \text { shock }_{h}=1, \text { post }_{t}=1, \mathbb{1}_{\{\text {group }=1\}}=1\right] \times P\left(\text { Capital }=\text { Yes } \mid E_{1}\right)+ \\
E\left[y_{h t} \mid \text { shock }_{h}=1, \text { post }_{t}=1, \mathbb{1}_{\{\text {group }=3\}}=1\right] \times P\left(\text { Capital }=N o \mid E_{1}\right) \\
E\left[y_{h t} \mid E_{1}\right]=\left(\tilde{\alpha}+\tilde{\beta_{0}}+\tilde{\beta}_{1}+\tilde{\delta_{h}}+\tilde{\mu_{t}}\right) \cdot P\left(\text { Capital }=\text { Yes } \mid E_{1}\right)+\left(\tilde{\alpha}+\tilde{\beta}_{0}+\tilde{\beta}_{3}+\tilde{\delta_{h}}+\tilde{\mu_{t}}\right) \cdot P\left(\text { Capital }=\text { No } \mid E_{1}\right)
\end{gathered}
$$


In case of event $E_{0}$, we have:

$$
\begin{gathered}
E\left[y_{h t} \mid E_{0}\right]=E\left[y_{h t} \mid \text { shock }_{h}=1, \text { post }_{t}=1, \mathbb{1}_{\text {\{group }=2\}}=1\right] \times P\left(\text { Capital }=Y \text { es } \mid E_{0}\right)+ \\
E\left[y_{h t} \mid \text { shock }_{h}=1, \text { post }_{t}=1, \mathbb{1}_{\{\text {group }=0\}}=1\right] \times P\left(\text { Capital }=N o \mid E_{0}\right) \\
E\left[y_{h t} \mid E_{0}\right]=\left(\tilde{\alpha}+\tilde{\beta}_{0}+\tilde{\beta}_{2}+\tilde{\delta_{h}}+\tilde{\mu_{t}}\right) \cdot P\left(\text { Capital }=Y e s \mid E_{0}\right)+\left(\tilde{\alpha}+\tilde{\beta_{0}}+\tilde{\delta_{h}}+\tilde{\mu_{t}}\right) \cdot P\left(\text { Capital }=N_{o} \mid E_{0}\right)
\end{gathered}
$$

Combining these equations, our interest parameter $\beta_{1}$ in equation 1 is obtained by :

$$
\begin{aligned}
\beta_{1} & =E\left[y_{h t} \mid E_{1}\right]-E\left[y_{h t} \mid E_{0}\right] \\
& =\tilde{\beta_{1}} \cdot P\left(\text { Capital }=\text { Yes } \mid E_{1}\right)+\tilde{\beta}_{3} \cdot P\left(\text { Capital }=N o \mid E_{1}\right)-\tilde{\beta}_{2} \cdot P\left(\text { Capital }=\text { Yes } \mid E_{0}\right)
\end{aligned}
$$

Finally, $\hat{\beta}_{1}$ is the estimator of $\tilde{\beta}_{3}+\left(\tilde{\beta}_{1}-\tilde{\beta}_{3}\right) \cdot P\left(\right.$ Capital $=$ Yes $\left.\mid E_{1}\right)-\tilde{\beta}_{2} \cdot P\left(\right.$ Capital $\left.=Y e s \mid E_{0}\right)$ in sample.

\section{B. Supplemental tables and graphs}

Table B.1: Sector of activity by shock statue (\% Adults)

\begin{tabular}{lcccc}
\hline \multirow{2}{*}{ Sector } & $\begin{array}{c}\text { Shocked } \\
(1)\end{array}$ & $\begin{array}{c}\text { Unshocked } \\
(2)\end{array}$ & $\begin{array}{c}\text { Difference } \\
(1)-(2)\end{array}$ & T-stat \\
\hline Agriculture & 0.31 & 0.68 & -0.37 & -1.32 \\
Mining & 0.22 & 0.01 & 0.21 & $2.58^{* * *}$ \\
Manufacturing & 0.84 & 0.64 & 0.20 & 0.75 \\
Professional/scientific/Technical & 0.30 & 0.52 & -0.22 & -0.95 \\
Electricity/water/gas/waste & 0.81 & 0.06 & 0.75 & $2.92^{* * *}$ \\
Construction & 0.88 & 0.75 & 0.13 & 0.43 \\
Transportation & 0.40 & 0.72 & -0.32 & -1.34 \\
Buying and selling & 0.54 & 0.67 & -0.13 & -0.58 \\
Financial/insurance/reast est. & 0.23 & 0.29 & -0.05 & -0.27 \\
Personal services & 2.43 & 1.00 & 1.43 & $3.300^{* * *}$ \\
Education & 4.55 & 2.31 & 2.25 & $3.61^{* * *}$ \\
Health & 1.29 & 0.64 & 0.65 & $2.05^{* * *}$ \\
Public Administration & 1.90 & 2.27 & -0.36 & -0.77 \\
Other & 0.27 & 0.41 & -0.14 & -0.71 \\
\hline Observations & 725 & 1225 & 1950 & \\
\hline \hline
\end{tabular}

${ }^{*} p<0.1,{ }^{* *} p<0.05,{ }^{* * *} p<0.001$ 
Table B.2: Parallel trend hypothesis

\begin{tabular}{lc}
\hline \multicolumn{2}{c}{ Dependent variable: Food insecurity score } \\
\hline Time (Ref $=$ planting 2018) \\
harvest 2019 \\
May 2020 & $-0.37^{* * *}$ \\
& $0.56^{* * *}$ \\
Business closure (Yes $/$ No) $\times$ Round & $(0.06)$ \\
(ref: Business closure $=$ No; Round $=$ Planting 2018$)$ & \\
Yes $\times$ Harvest 2019 & -0.02 \\
& $(0.08)$ \\
Yes $\times$ May 2020 & $0.18^{*}$ \\
& $(0.10)$ \\
Constant & $0.96^{* * *}$ \\
& $(0.02)$ \\
\hline Observations & 5850 \\
Adjusted $R^{2}$ & 0.242 \\
\hline Robust Standard errors in parentheses; ${ }^{*} p<0.1,{ }^{* *} p<0.05$
\end{tabular}

Table B.3: Capital channel hypothesis test by origin of remittances

\begin{tabular}{|c|c|c|c|c|}
\hline & \multicolumn{4}{|c|}{ Definition of the capital } \\
\hline & $\begin{array}{l}\text { Pooled } \\
\text { capital } \\
(1)\end{array}$ & $\begin{array}{c}\text { Formal } \\
\text { Financial } \\
\text { Services } \\
(2)\end{array}$ & $\begin{array}{c}\text { Informal } \\
\text { Financial } \\
\text { Services } \\
\quad(3)\end{array}$ & $\begin{array}{c}\text { Livestock } \\
\text { ownership, } \\
\text { Rental } \\
\text { earnings } \\
(4)\end{array}$ \\
\hline Lockdown-due business closure & $\begin{array}{c}0.40^{*} \\
(0.22)\end{array}$ & $\begin{array}{l}0.48^{* *} \\
(0.22)\end{array}$ & $\begin{array}{l}0.44^{*} \\
(0.22)\end{array}$ & $\begin{array}{c}0.49^{* *} \\
(0.23)\end{array}$ \\
\hline \multicolumn{5}{|c|}{ Lockdown-due business closure x Savings group $($ Ref: Capital $=$ No, remittance $=$ No $)$} \\
\hline Closure $=$ Yes $\times($ Capital $=$ Yes, Int. remit. $=$ Yes $)$ & $\begin{array}{c}-0.80^{* *} \\
(0.35)\end{array}$ & $\begin{array}{c}-1.01^{* * *} \\
(0.29)\end{array}$ & $\begin{array}{c}0.23 \\
(0.45)\end{array}$ & $\begin{array}{c}-1.08^{* * *} \\
(0.34)\end{array}$ \\
\hline Closure $=$ Yes $\times($ Capital $=$ Yes, Dom. remit. $=$ Yes $)$ & $\begin{array}{c}-0.42^{*} \\
(0.24)\end{array}$ & $\begin{array}{c}-0.46^{*} \\
(0.24)\end{array}$ & $\begin{array}{l}-0.12 \\
(0.27)\end{array}$ & $\begin{array}{c}-0.90^{* * *} \\
(0.28)\end{array}$ \\
\hline Closure $=$ Yes $\times($ Capital $=$ Yes, Int. \& Dom remit. $=$ No $)$ & $\begin{array}{l}-0.12 \\
(0.23)\end{array}$ & $\begin{array}{l}-0.26 \\
(0.24)\end{array}$ & $\begin{array}{c}0.01 \\
(0.24)\end{array}$ & $\begin{array}{l}-0.03 \\
(0.29)\end{array}$ \\
\hline Closure $=$ Yes $\times($ Capital $=$ No, Int. remit. $=$ Yes $)$ & $\begin{array}{l}-0.15 \\
(0.21)\end{array}$ & $\begin{array}{l}-0.15 \\
(0.21)\end{array}$ & $\begin{array}{l}-0.15 \\
(0.21)\end{array}$ & $\begin{array}{l}-0.15 \\
(0.21)\end{array}$ \\
\hline Closure $=$ Yes $\times($ Capital $=$ No, Dom. remit. $=$ Yes $)$ & $\begin{array}{l}-0.39 \\
(0.39)\end{array}$ & $\begin{array}{l}-0.39 \\
(0.39)\end{array}$ & $\begin{array}{l}-0.39 \\
(0.39)\end{array}$ & $\begin{array}{l}-0.39 \\
(0.39)\end{array}$ \\
\hline Time fixed effects & Yes & Yes & Yes & Yes \\
\hline Household fixed effects & Yes & Yes & Yes & Yes \\
\hline Constant & $\begin{array}{c}0.96^{* * *} \\
(0.03)\end{array}$ & $\begin{array}{c}0.97^{* * *} \\
(0.03)\end{array}$ & $\begin{array}{c}0.92^{* * *} \\
(0.03)\end{array}$ & $\begin{array}{c}1.02^{* * *} \\
(0.04)\end{array}$ \\
\hline Observations & 5433 & 4671 & 3132 & 1995 \\
\hline Adjusted $R^{2}$ & 0.243 & 0.213 & 0.253 & 0.216 \\
\hline
\end{tabular}

Standard errors in parentheses

${ }^{*} p<0.1,{ }^{* *} p<0.05,{ }^{* * *} p<0.01$ 
Table B.5: Sample distribution over rounds

\begin{tabular}{lccc}
\hline Round & Not-shocked & Shocked & Total \\
\hline May-20 & 1233 & 730 & 1963 \\
$\%$ & 63 & 37 & 100 \\
Jun-20 & 1656 & 174 & 1830 \\
$\%$ & 90 & 10 & 100 \\
Jul-20 & 1728 & 66 & 1794 \\
$\%$ & 96 & 4 & 100 \\
Aug-20 & 1762 & 36 & 1798 \\
$\%$ & 98 & 2 & 100 \\
\hline
\end{tabular}

Table B.6: Remittances' mitigating effect: robustness to Food Insecurity definition

\begin{tabular}{|c|c|c|c|c|c|c|}
\hline \multirow[t]{2}{*}{ Dependent variable } & \multicolumn{2}{|c|}{$\begin{array}{l}\text { Likelihood } \\
\text { to skip a meal }\end{array}$} & \multicolumn{2}{|c|}{$\begin{array}{l}\text { Likelihood } \\
\text { to run out } \\
\text { of food }\end{array}$} & \multicolumn{2}{|c|}{$\begin{array}{l}\text { Likelihood to } \\
\text { not eat for } \\
\text { a whole day }\end{array}$} \\
\hline & (1) & $(2)$ & $(3)$ & $(4)$ & $(5)$ & (6) \\
\hline Lockdown-due business closure & $\begin{array}{c}0.11^{* * *} \\
(0.04)\end{array}$ & $\begin{array}{c}0.11^{* * *} \\
(0.04)\end{array}$ & $\begin{array}{l}0.07^{*} \\
(0.04)\end{array}$ & $\begin{array}{l}0.07^{*} \\
(0.04)\end{array}$ & $\begin{array}{l}0.11^{* *} \\
(0.04)\end{array}$ & $\begin{array}{l}0.11^{* *} \\
(0.04)\end{array}$ \\
\hline $\begin{array}{l}\text { All remittances } 2018 / 2019 \\
\times \text { Lockdown-due business closure }\end{array}$ & $\begin{array}{l}-0.10^{*} \\
(0.05)\end{array}$ & - & $\begin{array}{l}-0.11^{*} \\
(0.06)\end{array}$ & - & $\begin{array}{c}-0.13^{* *} \\
(0.06)\end{array}$ & - \\
\hline $\begin{array}{l}\text { International remittances } 2018 / 2019 \\
\times \text { Lockdown-due business closure }\end{array}$ & - & $\begin{array}{l}-0.24^{*} \\
(0.12)\end{array}$ & - & $\begin{array}{l}-0.29 \\
(0.20)\end{array}$ & - & $\begin{array}{l}-0.16 \\
(0.15)\end{array}$ \\
\hline $\begin{array}{l}\text { Domestic remittances } 2018 / 2019 \\
\times \text { Lockdown-due business closure }\end{array}$ & - & $\begin{array}{l}-0.08 \\
(0.06)\end{array}$ & - & $\begin{array}{l}-0.09 \\
(0.06)\end{array}$ & - & $\begin{array}{c}-0.12^{* *} \\
(0.06)\end{array}$ \\
\hline $\begin{array}{l}\text { Household fixed effects } \\
\text { Constant }\end{array}$ & $\begin{array}{c}\text { Yes } \\
0.43^{* * *} \\
(0.01)\end{array}$ & $\begin{array}{c}\text { Yes } \\
0.43^{* * *} \\
(0.01)\end{array}$ & $\begin{array}{c}\text { Yes } \\
0.39^{* * *} \\
(0.01)\end{array}$ & $\begin{array}{c}\text { Yes } \\
0.39^{* * *} \\
(0.01)\end{array}$ & $\begin{array}{c}\text { Yes } \\
0.14^{* * *} \\
(0.01)\end{array}$ & $\begin{array}{c}\text { Yes } \\
0.14^{* * *} \\
(0.01)\end{array}$ \\
\hline $\begin{array}{l}\text { Observations } \\
\text { Adjusted } R^{2}\end{array}$ & $\begin{array}{l}5850 \\
0.255\end{array}$ & $\begin{array}{l}5850 \\
0.256\end{array}$ & $\begin{array}{l}5850 \\
0.136\end{array}$ & $\begin{array}{l}5850 \\
0.137\end{array}$ & $\begin{array}{c}5850 \\
0.090\end{array}$ & $\begin{array}{c}5850 \\
0.090\end{array}$ \\
\hline
\end{tabular}


Figure B.1: Parallel trend hypothesis test

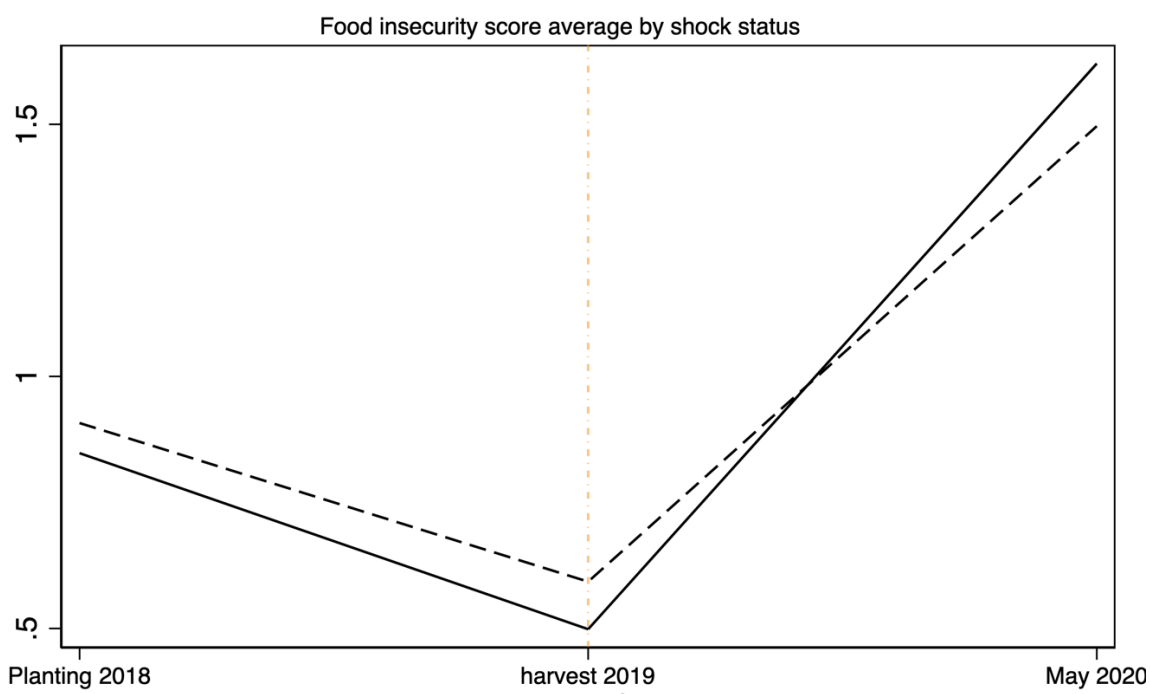

Source: GHS wave 4 (2018/2019), COVID-19 NLPS 2020, Authors' calculations.

Table B.4: Dictionary of variables used

\begin{tabular}{|c|c|c|}
\hline Variables & Questionnaire used & Questions considered \\
\hline $\begin{array}{l}\text { COVID-19 employment } \\
\text { shock }\end{array}$ & $\begin{array}{l}\text { COVID-19 NLPS } 2020 \text { baseline } \\
\text { household questionnaire }\end{array}$ & $\begin{array}{l}\text { 1. Were you working before mid- } \\
\text { March? (Yes/No) } \\
\text { 2. What was the main reason you } \\
\text { stopped working? } \\
\text { - Business/Office closed due to } \\
\text { coronavirus legal restrictions } \\
\text { - Not able to go to farm due to } \\
\text { movement restrictions }\end{array}$ \\
\hline Remittances & $\begin{array}{l}\text { Nigeria General Household } \\
\text { Survey - Panel Wave 4, 2018- } \\
\text { 2019, Post-Harvest } \\
\text { Community Questionnaire }\end{array}$ & $\begin{array}{l}\text { 1. In the past } 12 \text { months, did [NAME] } \\
\text { receive any of the following } \\
\text { assistance from a non-household } \\
\text { member? (Yes/No) } \\
\text { - FROM ABROAD } \\
\text { A. Monetary assistance } \\
\text { B. In-kind assistance } \\
\text { - FROM WITHIN NIGERIA } \\
\text { A. Monetary assistance } \\
\text { B. In-kind assistance }\end{array}$ \\
\hline Food insecurity & $\begin{array}{l}\text { COVID-19 NLPS } 2020 \\
\text { baseline household } \\
\text { questionnaire } \\
\text { - Nigeria General Household } \\
\text { Survey - Panel Wave 4, } \\
\text { 2018-2019, Post-Harvest } \\
\text { Community Questionnaire. }\end{array}$ & $\begin{array}{l}\text { 1. You, or any other adult in your } \\
\text { household, had to skip a meal } \\
\text { because there was not enough } \\
\text { money or other resources to } \\
\text { get food? (Yes/No) } \\
\text { 2. Your household ran out of } \\
\text { food because of a lack of } \\
\text { money or other resources? (Yes/No) } \\
\text { 3. You, or any other adult in your } \\
\text { household, went without } \\
\text { eating for a whole day } \\
\text { because of a lack of money or } \\
\text { other resources? (Yes/No) }\end{array}$ \\
\hline
\end{tabular}

